\title{
Bieg z przeszkodami. Ambiwalencje sukcesu artystycznego w poszerzonym polu kultury
}

\author{
Krzysztof Stachura \\ Uniwersytet Gdański
}

DOI: http://dx.doi.org/10.18778/1733-8069.16.2.07

\section{Słowa kluczowe: sukces artystyczny, strategie adaptacji, dynamika karier, poszerzenie pola kultury, sektor kultury}

Abstrakt: Celem artykułu jest analiza ambiwalentnego charakteru kategorii sukcesu w świecie społecznym artystów. W tekście przedstawiam znaczenia sukcesu z perspektywy twórców, osadzając narracje zogniskowane wokół sukcesu w kontekście przemian poszerzonego pola kultury. Wyjaśniam, jakie znaczenie ma transformacja pola kultury dla strategii adaptacyjnych stosowanych przez artystów. Odwołując się do prekarnych doświadczeń twórców, dokonuję rekonstrukcji sposobów zarządzania przez nich ich własnymi karierami. Bazując na zebranym materiale empirycznym, próbuję jednocześnie odpowiedzieć na pytanie o trudności i wątpliwości związane z osiąganiem sukcesu w środowisku artystycznym oraz opisać uwarunkowania defensywno-kompensacyjnej strategii zarządzania sukcesem. W zakończeniu tekstu formułuję wnioski dotyczące sposobów hakowania przez artystów reguł gry zainstalowanych w poszerzonym polu kultury.

Krzysztof Stachura, doktor socjologii, adiunkt w Zakładzie Antropologii Społecznej w Instytucie Socjologii Uniwersytetu Gdańskiego. Interesuje się badaniami przemian formuł uczestnictwa w kulturze, antropologią nowych technologii i metodologicznymi aspektami badań prowadzonych online. Autor książki Towarzyskość jako forma uspołecznienia w epoce cyfrowej (2018).

\author{
Adres kontaktowy: \\ Zakład Antropologii Społecznej \\ Instytut Socjologii \\ Uniwersytet Gdański \\ ul. Jana Bażyńskiego 4 \\ 80-309 Gdańsk \\ e-mail: wnsks@ug.edu.pl
}




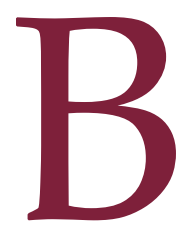

adania środowisk artystycznych w Polsce od pewnego czasu wyraźnie zyskują na popularności. Po relatywnie długim okresie niskiego poziomu zainteresowania tą tematyką (przede wszystkim na gruncie socjologii i antropologii) w minionych latach powstały opracowania, w których podejmuje się problematykę światów artystycznych, sytuacji artystów w polu kultury i uwarunkowań uprawiania przez nich twórczości. Analizy poświęcone są różnym wymiarom społecznego funkcjonowania artystów (Kozłowski, Sowa, Szreder 2014a; Ilczuk i in. 2015; Bachórz, Stachura 2015a; Krajewski, Schmidt 2017), konkretnym grupom twórców (Walczak, Wyrzykowska, Socha 2016; Folga-Januszewska, Kiliszek [red.] 2018; Łuczaj 2018; Wyrzykowska, Zawadzka 2018), ale też szczegółowym problemom związanym z obecnością artystów w życiu publicznym (Kowalewski, Nowak, Thurow 2015; Murzyn-Kupisz, Działek [red.] 2017; Możdżyński 2018; Szreder 2018).

Niniejszy tekst wpisuje się w toczącą się w Polsce - choć, oczywiście, nie tylko lokalnie interesującą debatę na temat kondycji środowiska artystycznego. Dotyczy zagadnienia relatywnie słabo obecnego $\mathrm{w}$ istniejącej literaturze przedmiotu, jakim jest sukces. W wyobrażeniach i doświadczeniach artystów sukces jest kategorią niejednoznaczną i nieoczywistą, a sukces może być interpretowany jako niepowodzenie (Heinich 2007). Od określenia "sukces” artyści się dystansują i próbują je relatywizować. Mówią przy tym o sukcesie jako o czymś, co trudno zmierzyć i co można wpisać w perspektywę żmudnego, nielinearnego procesu. Rekonstrukcja narracji o sukcesie nie byłaby jednak w pełni zrozumiała bez nakreślenia uwarunkowań społecznych, w których dążenie do osiągnięcia sukcesu staje się możliwe. Analiza sposobów rozumienia tego, czym jest tytułowy sukces, jest więc osadzona w charakterystyce osiowych przemian funkcjonowania środowisk artystycznych. Te z kolei stanowią pochodną generalnych tendencji transformacji świata kultury, z logiką poszerzenia pola kultury na czele (Czarnecki i in. 2012).

W tekście staram się odpowiedzieć na pytanie o to, jak ewolucja myślenia o kulturze i działania w kulturze, znajdująca swoje odzwierciedlenie w procesach poszerzenia pola kultury, wpływa na stosunek do sukcesu, strategie jego osiągania i uwarunkowania dynamiki karier twórców. Tytułowa metafora biegu z przeszkodami sugeruje, że artystom trudno jest taki status osiągać i utrzymać. W dalszej części tekstu obrazuję, dlaczego tak jest, wskazując na ambiwalentny sens sukcesu artystycznego i ukazując „zmagania z sukcesem” na tle przemian sektora kultury i miejsca, jakie zajmują w nim artyści. Jako kontekst interesują mnie strategie adaptacji artystów w polu kultury oraz logika dynamiki ich zawodowych karier. Piszę więc o mechanizmach, które mają kluczowy wpływ na to, czy i jaki sukces jest dziś możliwy lub prawdopodobny w świecie społecznym artystów - przede wszystkim ekonomizacji i instrumentalizacji działalności twórczej, odczuciu niepewności, jakie związane jest z twórczością, walkach o autonomię, a także przemianach ról artystów, które wiążą się z tymi procesami. Kondycja społeczno-zawodowa artystów w dalszym ciągu zależy także od innych czynników (w tym, przede wszystkim, specyfiki polskich polityk kulturalnych oraz postaw względem sztuki i kompetencji kulturowych Polaków), ale znaczenie uwarunkowań poszerzeniowych systematycznie rośnie.

W badaniach, do których będę się odwoływał, środowisko artystyczne rozumiane jest szeroko, co niewątpliwie należy mieć na uwadze, przyglądając 
się wnioskom z przeprowadzonej analizy. W wielu innych opracowaniach definicje artystów i środowiska artystycznego są bardziej ekskluzywne lub skupiają się na pewnym wycinku pola twórców. Pomimo różnic w sposobie definiowania i wyznaczania granic światów artystycznych widocznych jest wiele punktów stycznych w zakresie specyfiki strategii adaptacyjnych artystów i dynamiki konstruowania przez nich ich własnych karier. Jednocześnie, choć podkreślam $\mathrm{w}$ dwóch pierwszych akapitach koncentrację na badaniu środowisk twórczych w Polsce, a lokalne uwarunkowania uznaję za główny przedmiot zainteresowania badawczego, za zasadne uważam podkreślenie uniwersalnego, charakterystycznego dla niemal wszystkich państw wysoko rozwiniętych, charakteru presji i napięć, jakie wiążą się z uprawianiem zawodów twórczych w czasach późnego kapitalizmu.

\section{Koncepcja teoretyczna}

\section{Meandry logiki poszerzeniowej}

Ożywienie $\mathrm{w}$ ostatnich latach naukowej debaty o kondycji środowisk artystycznych stanowi pochodną wzrostu poziomu zainteresowania przemianami w polu kultury - zarówno w jej ujęciu sektorowym, jak i w kontekście ewolucji funkcji przypisywanych i nadawanych kulturze (Bachórz, Stachura 2015b). Współczesny dyskurs o kulturze akcentuje odrzucenie jej centralistycznej wizji i wzrost poziomu podmiotowości aktorów podejmujących różnorodne praktyki kulturowe. Pole kultury ulega procesom demokratyzacji - z hierarchicznym centralizmem walczy oddolny egalitaryzm, zwiększa się też liczba kulturalnych centrów decyzyjnych. Równolegle coraz częściej o kulturze mówi się i pisze, że jest „żywa”" (Fatyga 2017) i „,szeroka” (Dobosz, Jarmuł, Poręba [red.] 2011), zaś uczestnictwo w niej
- „relacyjne” (Krajewski 2013). Szczególnie ciekawie przebiegają tego rodzaju zmiany w krajach postsocjalistycznych, w których transformacja ustrojowa otworzyła nie tylko nowe możliwości partycypacji w kulturze, ale też przestrzeń do rekonstrukcji istniejącego układu instytucji kultury czy sposobów zarządzania politykami kulturalnymi.

W efekcie zmian charakterystycznych dla późnej nowoczesności pole kultury przyjmuje bardziej hybrydową, niejednolitą formę. Na szeroką skalę rozwija się proces kulturalizacji świata społecznego, czyli przenikania kultury w przestrzenie wcześniej z nią słabiej związane (edukacji, polityki społecznej, rynku pracy czy gospodarki). Pole kultury staje się przez to bardziej usieciowione - relacje komunikacyjne gęstnieją, a obecni w nim aktorzy muszą poszukiwać nowych formuł i strategii adaptacji (Bachórz i in. 2019). Sama kultura zaczyna być postrzegana jako narzędzie inkluzji, platforma wzmacniania spójności społecznej, mechanizm wyrównywania szans i podnoszenia jakości życia - swoista czarna skrzynka, która ma stanowić odpowiedź na szereg wyzwań, z jakimi borykają się dziś rozwinięte społeczeństwa (Kłosowski [red.] 2011; Fatyga, Dudkiewicz, Tomanek 2012).

Wiele z sygnalizowanych powyżej procesów można umieścić w kontekście i opisać przez pryzmat zjawiska poszerzenia pola kultury. Logika poszerzeniowa z jednej strony pozwala dostrzec i spróbować scharakteryzować przemiany związane z aktywnością $\mathrm{w}$ pozainstytucjonalnych sferach sektora kultury, z drugiej zaś stanowi koncepcyjną odpowiedź na problem przemian procesów uczestnictwa i instrumentalizowania praktyk kulturalnych, w tym opisywanego wyżej wiązania ich z aktywnościami i działaniami w innych sektorach życia publicznego. Myślenie kategoriami poszerzeniowymi pozwa- 
la lepiej rozumieć załamywanie się tradycyjnych podziałów i regulacji sektorowych, tłumacząc przy tym naturę transgresji instytucjonalnej oraz związanego z nią pojawienia się na kulturalnej scenie nowych aktorów (Czarnecki i in. 2012).

Z punktu widzenia potencjału animowania i ożywiania działań artystycznych, a docelowo także wpływu na trajektorie karier oraz strategie osiągania sukcesu przez twórców, szczególnie istotne są trzy wymiary poszerzenia pola kultury. Po pierwsze, logika poszerzeniowa zakłada, w pewnym uproszczeniu, realizację poprzez kulturę celów społecznych. Kultura ma więc być nośnikiem uspołecznienia, narzędziem społecznego włączenia i upodmiotowienia. Role twórców wykraczają dziś wyraźnie poza „uprawianie sztuki”, stąd ważne jest, by diagnozować, jak poszerzona pod względem celów kultura przekłada się na specyfikę i dynamikę działań twórców, a także jakie wyznacza im społeczne zadania. Po drugie, przejawem poszerzenia pola kultury jest wypracowanie nowych formuł działań i nowych kontekstów, w których „dzieje się" kultura. Dla artystów może to oznaczać prowadzenie aktywności w przestrzeniach publicznych, podejmowanie artystycznych eksperymentów czy animowanie nowych sposobów działań zbiorowych. Po trzecie, w obszarze oferty i sposobu jej odbioru chodzi o to, by kultura była relatywnie łatwo dostępna, uczestnicy mieli możliwość stawania się jej (współ)twórcami, a treści kultury można było odbierać na różnych płaszczyznach, z wykorzystaniem wielu zmysłów. $W$ takich warunkach artyści mogą pełnić funkcje akuszerów oddolnej twórczości amatorskiej, informatorów i edukatorów wprowadzających w świat praktyk kulturalnych.

Logika poszerzeniowa nie „wymyśliła” wyżej wymienionych obszarów działalności artystycznej, jakie można wpisać w poszczególne wymiary poszerzenia pola kultury. Niewątpliwie jednak przynajmniej w części je odkrywa, a w znacznej mierze także dowartościowuje i sankcjonuje. Legitymizuje wiele różnych wymiarów działalności podejmowanych przez twórców, wpływając tym samym z jednej strony na rekonfigurację układu kultury, $\mathrm{z}$ drugiej na pozycję artystów w polu. Jest to proces o kluczowym znaczeniu, którego konsekwencją może być istotne przesunięcie w sposobie budowania karier artystycznych. Poszerzenie pola kultury nie tylko jednak pozwala na wydobycie i uznanie aktywności twórczych o różnym charakterze, ale otwiera również nowe możliwości działań. Artyści mogą więc wchodzić w role wcześniej w mniejszym stopniu dla nich dostępne czy takie, które dopiero powstają (na przykład planistów kulturowych czy konsultantów ds. rewitalizacji przestrzeni publicznych).

Stanowiących odpowiedź na zmiany w kulturze procesów poszerzeniowych nie należy też rozumieć jako kulturowego końca historii - ewolucji w kierunku coraz większej liczby możliwości, ofert i propozycji. W program poszerzeniowy wpisanych jest bowiem wiele sprzeczności i nieoczywistości. Poszerzenie pola bez zwiększenia puli zasobów (przede wszystkim finansowych, logistycznych, kadrowych i kompetencyjnych) doprowadzi do jego większej przepuszczalności, zaś zagęszczenie sieci w części pola może skutkować jego pustynnieniem $\mathrm{w}$ innym miejscu. Pojawienie się w polu nowych aktorów, wynikające z kulturalizacji innych sektorów życia publicznego, wzmaga konkurencję - o środ$\mathrm{ki}$, o dostęp do centralnych pozycji pola, o uznanie i prestiż, o szanse na osiągnięcie tytułowego sukcesu. Poszerzenie może też paradoksalnie zachęcać do wypychania tradycyjnych aktorów z sektora kultury do innych sektorów życia publicznego, osłabia- 
jąc tym samym ich zakorzenienie w sieciach opartych na wiązaniach właściwych dla świata kultury. W polu toczyć się więc będą spory i walki o autonomię, władzę i uprawomocnienie.

W takich warunkach procesom demokratyzacji kultury towarzyszy odtwarzanie w nowej formie tradycyjnych dychotomii (Bachórz i in. 2016; Błaszczyk, Cebula 2016; Sadura 2017). Negatywnym skutkiem ubocznym działań w zrekonstruowanym, „,wzmocnionym" polu kultury jest też kontrola przez inkluzję, czyli włączenie do centralnego obiegu kultury treści o potencjale krytycznym, które w drodze uzyskiwania stabilizacji i zwiększania skali uzależniają się od zasobów ze środków publicznych, tracąc swój alternatywny charakter (Lewicki, Filiciak 2017). Taki proces jest szczególnie groźny dla przedstawicieli nieformalnych środowisk twórczych, których fundamentem działalności często jest niestandardowa, offowa formuła oferty. Odpowiedzią na te trudności i wyzwania mogłaby być przemyślana, konstruktywistyczna poszerzeniowa polityka kulturalna, bazująca na uspołecznianiu kultury i uwzględnieniu $\mathrm{w}$ formułowaniu reguł gry przede wszystkim głosu oddolnego, nie zaś taka, które konserwuje hierarchiczny, odgórnie normowany układ relacji między aktorami (Krajewski 2017).

\section{Od inkluzywnej definicji do świata społecznego}

Definicje, role i funkcje artystów zmieniają się wraz z przemianami pola kultury. Zakres tego, kim są i czym zajmują się artyści, różni się $\mathrm{w}$ zależności od przyjętych kryteriów analitycznych. Do logiki funkcjonowania $\mathrm{w}$ poszerzonym polu kultury dobrze dopasowana jest inkluzywna definicja artysty. Na jej mocy artystami nazywa się osoby, które albo same siebie uważają za artystów, albo w taki sposób są postrzegane przez innych. Warto podkreślić, że o ile ta definicja może wydawać się adekwatna do współczesnych realiów, ten sposób definiowania tego, kim jest artysta, ma długą historię (Znaniecki 1937; Osęka 1975). Warto podkreślić, że demokratyzacja kultury nie tylko czyni inkluzywne definicje środowisk artystycznych zasadnymi, ale otwiera pole do rozszerzania zakresu pojęciowego kategorii twórców. Artystami nazywani mogą być więc fryzjerzy, serowarzy, piekarze i wybitni sportowcy (Krajewski, Schmidt 2017).

Inkluzywna definicja artysty, jakkolwiek z wielu względów wydaje się konceptualnie ciekawa, jest też problematyczna. Poszerzanie definicji tego, kogo można określić mianem artysty, prowadzi do rozmywania się tej kategorii i utrudnia poszukiwanie punktów wspólnych dla różnych grup twórców, znacznie różniących się od siebie charakterem wykonywanych czynności. Inkluzywna definicja artysty generuje też liczne napięcia związane z tym, kogo i w jaki sposób obejmować wsparciem ze środków publicznych, którzy twórcy winni znajdować się w orbicie zainteresowania instytucji kultury oraz którzy są godni uwagi i zainteresowania. Wszystkie te kwestie nie pozostają bez znaczenia dla specyfiki artystycznej kariery i zmagań z tym, jak osiągać sukces. Z uwagi na charakter prowadzonej narracji zdecydowałem się pisać o artystach jako o przedstawicielach określonej grupy społeczno-zawodowej, bez szczegółowego różnicowania jej ze względu, na przykład, na reprezentowany rodzaj sztuki.

Niezależnie od sposobu definiowania tego, kim jest artysta i co wyznacza ramy środowiska artystycznego, twórców można ujmować przez pryzmat klasycznej kategorii światów społecznych (Shibutani 1955; Strauss 1978). Centralnym punktem każdego świata społecznego są toczące się w jego obrębie procesy komunikacyjne i określone uniwersum 
dyskursu. Dzięki temu możliwe jest, by aktorzy z danego świata uczestniczyli w aktach symbolicznej wymiany, toczyli spory i prowadzili negocjacje na właściwych dla danego świata arenach. Podstawą świata społecznego są czynności, wokół których tworzą się wspólne kody kulturowe. W przypadku świata społecznego artystów taką osiową czynnością może być aktywność artystyczna, a spór na arenie dotyczyć tego, jakie aktywności są w danym świecie legitymizowane, kto dysponuje symbolicznym kapitałem do określania pozycji własnej i innych twórców, jak również gdzie znajdują się granice poszczególnych światów. Naturalnym elementem tych procesów będzie też różnicowanie się świata społecznego artystów na subświaty, w których dochodzić będzie do analogicznych zjawisk na mniejszą skalę.

Koncepcja światów społecznych jest przydatna w rozumieniu reguł gry, jakie panują w polu artystycznym, a szerzej - także w polu kultury. Pole w rozumieniu przyjętym $w$ tekście definiowane jest przede wszystkim w kategoriach sektorowych, a dodatkowo jako platforma, która może „pomieścić” określone funkcje przypisywane kulturze. Świat społeczny akcentuje natomiast przede wszystkim relacje między aktorami, którzy go wypełniają, pozwalając przy tym na odkrywanie uwarunkowań i konsekwencji kontaktów, do których dochodzi w ramach danego świata. Zróżnicowany, wewnętrznie podzielony na subświaty świat społeczny może być przedmiotem analizy jako ważny podmiot poszerzonego pola kultury. Jego wielowymiarowy i heterogeniczny charakter jest też właściwy specyfice szerokiej i żywej kultury. W świecie społecznym artystów obok siebie funkcjonują więc, jak zauważają Marek Krajewski i Filip Schmidt (2017), artyści-menedżerowie i aktywiści, artyści uprawiający intensywną autopromocję i ci, którzy nie przywiązują do tego tak dużej wagi, zwolennicy tradycyjnych formuł twórczości i twórcy poszukujący nowych wyzwań wypracowywanych na styku pracowni artystycznej i biotechnologicznego laboratorium.

\section{Materiał i metoda}

W dalszej części analizy wykorzystuję odwołania do materiału empirycznego z badań prowadzonych w 2015 roku na terenie całego województwa pomorskiego ${ }^{1}$. Motywem przewodnim realizowanego wówczas projektu była próba analizy trajektorii sukcesu artystycznego w środowiskach twórczych. Analiza pojęcia sukcesu prowadzona była w kontekście odkodowywania znaczeń nadawanych terminom „artysta” i „środowisko artystyczne” oraz specyfiki biografii artystów. Tłem dla tego rozpoznania była próba zrozumienia kondycji funkcjonowania świata społecznego artystów oraz uwarunkowań polityk publicznych w obszarze wsparcia środowisk artystycznych. Głównym efektem prowadzonych badań jest książka podsumowująca projekt (Bachórz, Stachura 2015a). Na potrzeby niniejszego artykułu przeprowadziłem ponowną analizę zebranego wówczas materiału empirycznego. $\mathrm{W}$ efekcie tego procesu wypracowane zostały nowe interpretacje i wnioski analityczne wykorzystane do zobrazowania sposobów postrzegania i rozumienia sukcesu w kontekście polityk poszerzonego pola kultury.

Zebrany materiał został poddany analizie w celu rozpoznania społeczno-kulturowego kontekstu

\footnotetext{
${ }^{1}$ Projekt pt. „Trajektorie sukcesu zawodowego. Strategie adaptacji artystów w polu kultury" (06161/15) realizowany był w ramach programu Obserwatorium Kultury finansowanego ze środków Ministerstwa Kultury i Dziedzictwa Narodowego. Poza autorem w skład zespołu badawczego wchodzili: Agata Bachórz, Monika Bokiniec, Natalia Brylowska, Tomasz Grabowski, Jakub Knera.
} 
funkcjonowania artystów oraz znaczeń, jakie nadają oni własnym działaniom (Blumer 2008). Interesowały mnie uwarunkowania codziennych trajektorii badanych oraz praktykowane przez nich strategie radzenia sobie $\mathrm{w}$ świecie społecznym twórców. Strategia analityczna oparta była na kodowaniu (kodowanie wstępne i kodowanie zogniskowane) zebranego materiału empirycznego w celu przedstawienia relacji między analizowanymi pojęciami i kategoriami (Charmaz 2009). Na potrzeby tekstu prowadziłem analizę danych pod kątem rekonstruowania sposobów zarządzania własnymi karierami przez artystów. Efektem tych zabiegów było wyróżnienie głównych wymiarów karier artystycznych (niepewność, procesualność) oraz odkrycie dominującej strategii zmagań z sukcesem (pragmatyzm, orientacja defensywno-kompensacyjna). Analizę materiału prowadziłem w duchu interpretatywnym, próbując z jednej strony zrozumieć, jak definiowane i urefleksyjniane są doświadczenia życiowe artystów (Denzin 1990), z drugiej zaś rozpoznać, jak jednostkowe uwarunkowania twórczości (ze szczególnym naciskiem na odniesienie do tytułowej kategorii sukcesu) składają się na kompleksowy układ relacji w środowiskach twórczych (Prus 1995).

Zasadnicza część badań miała charakter jakościowy - opierała się na indywidualnych wywiadach pogłębionych $\mathrm{z}$ artystami ( $\mathrm{n}=30$ ) i innymi przedstawicielami sektora kultury $(n=15)$ oraz zogniskowanych wywiadach grupowych z przedstawicielami obu tych środowisk ( $\mathrm{n}=36$ - łączna liczba badanych, którzy wzięli udział w sześciu spotkaniach). Łącznie w wywiadach wzięło udział 81 osób (53 artystów i 28 ludzi kultury). Przed realizacją wywiadów zespół badawczy przeprowadził analizę desk research opartą na kompleksowym studium literaturowym. Celem tej części badań było doprecyzowanie założeń do kolejnych modułów projektu. Wywiady poprzedziła też analiza treści przekazów internetowych, mająca zidentyfikować główne wątki debaty publicznej wokół specyfiki światów społecznych artystów i znaczeń nadawanych kategorii sukcesu.

Próba badawcza została skonstruowana zgodnie z opisanymi powyżej założeniami inkluzywnej definicji artysty oraz w sposób mający gwarantować maksymalne zróżnicowanie ze względu na szereg kryteriów. Wśród badanych znaleźli się przedstawiciele sztuk wizualnych, muzyki, filmu, teatru i tańca oraz muzyki. Dbano zarówno o porównywalną liczebność twórców z poszczególnych dziedzin, jak i o zróżnicowanie w ramach konkretnych subpól artystycznych (na przykład ze względu na gatunek wykonywanej muzyki). Artyści różnili się między sobą także miejscem zamieszkania i pracy (rdzeń regionu, duże ośrodki miejskie, małe ośrodki miejskie i wsie) oraz stażem działalności. Do grona dużych ośrodków miejskich zakwalifikowane główne siedziby subregionów w obrębie województwa (Chojnice, Malbork, Słupsk, Tczew, Wejherowo). Miejsce zamieszkania badanych nie było tożsame z miejscem uprawiania działalności artystycznej, choć część twórców prowadziła działania przede wszystkim w wymiarze lokalnym. W procesie analizy materiału empirycznego przyjęto założenie, że twórcy, którzy zajmują się uprawianiem działalności artystycznej przez okres do 5 lat, zostaną zakwalifikowani jako mało doświadczeni, zaś ci ze stażem 10 i więcej lat - jako doświadczeni. Osoby ze stażem artystycznym trwającym powyżej 5 do 10 lat były przydzielane do jednej z dwóch kategorii na podstawie subiektywnej oceny badaczy. Dodatkowo pod uwagę brane były: stopień sprofesjonalizowania działalności, zakres rozpoznawalności i skala utrzymywania się ze sztuki (artyści „profesjonalni” i artyści „amatorzy”). Kontrapunkt dla głosu arty- 
stów stanowiły wypowiedzi ludzi kultury. Wśród nich znaleźli się pracownicy instytucji, dziennikarze, urzędnicy, mecenasi kultury i dydaktycy z uczelni artystycznych.

W artykule zamieszczone zostały cytaty, które są fragmentami wypowiedzi rozmówców biorących udział $\mathrm{w}$ indywidualnych wywiadach pogłębionych lub zogniskowanych wywiadach grupowych. W oznaczeniach cytatów znajduje się informacja: (1) z jakiego rodzaju wywiadu pochodzi dany fragment (IDI / FGI); (2) czy rozmówca zalicza się do grupy artystów czy ludzi kultury (A / LK); (3) do jakiej grupy twórców można zaliczyć rozmówcę w oparciu o doświadczenie uprawiania działalności artystycznej (ND / D - dotyczy tylko artystów); (4) jaka jest dziedzina aktywności autora danej wypowiedzi (różne kategorie działalności artystycznej w przypadku twórców i pracy w sektorze kultury w przypadku ludzi kultury); (5) jakie jest miejsce zamieszkania rozmówcy (RDZEŃ - Trójmiasto, DOM - duży ośrodek miejski, MOM - mały ośrodek miejski / wieś).

\section{Wyniki}

\section{Skazani na prekarność? Uwarunkowania} doświadczania niepewności $\mathbf{w}$ poszerzonym polu kultury

W świetle omawianych badań można stwierdzić, że zasadniczym wymiarem definiującym świat społeczny artystów jest niepewność. Kondycja artystów znaczona jest niezdecydowaniem, niepokojem i wątpliwościami (zob. np. Wagner 2015). Ten stan jest pochodną wielu czynników, spośród których kluczowe znaczenie mają: trudności w utrzymywaniu się z pracy zawodowej w roli artysty, konieczność prowadzenia „podwójnego życia” (Lahire 2010), czyli łączenia funkcji artystycznych z podejmowaniem innych aktywności zawodowych, instrumentalizacja aktywności artystycznej oraz poczucie obcości w społeczeństwie, w którym artyści żyją i tworzą. Niepewność jest też konsekwencją rozmycia definicji tego, czym jest sztuka i jakie trzeba posiadać kompetencje i doświadczenie, by móc za artystę się uznawać.

Nadrzędnym powodem, który wpływa na odczuwanie niepewności, są uwarunkowania rynku pracy dla artystów oraz słabości systemu wsparcia twórców. W środowisku problemem są przede wszystkim nieregularne przychody, niepewność i niestabilność zatrudnienia oraz brak rozwiązań w zakresie ubezpieczeń zdrowotnych i zabezpieczenia emerytalno-rentowego. Dodatkowym problemem jest słabość systemu stypendialno-dotacyjnego (Ilczuk i in. 2015; Szulborska-Łukaszewicz 2017). W efekcie wielu artystów znajduje się w złej kondycji materialnej. Sytuacja ta nie dotyczy zresztą wyłącznie Polski. Przeciwnie, podobne warunki życia i twórczości stanowią doświadczenie twórców w wielu krajach na całym świecie (Abbing 2002). Problemem jest nie tylko niski poziom dochodów, ale też ich nieregularność, mogąca - w grupie artystów, którzy mogą utrzymywać się z wykonywania pracy artystycznej - skutkować na przykład trudnością w dostępie do kredytu hipotecznego (Kozłowski, Sowa, Szreder 2014b).

$\mathrm{Z}$ pracy $\mathrm{w}$ teatrze jest się bardzo trudno utrzymać. (...) Dlatego szuka się... Jeździ się na castingi i szuka się jakichś ról w filmach, reklamach. Teraz się podróżuje w poszukiwaniu pracy. Nawet ci etatowi aktorzy, którzy mają pracę $\mathrm{w}$ teatrze. Wiesz, etat $\mathrm{w}$ teatrze jest o tyle bezpieczny, że masz całą otoczkę, ZUS-y i tak dalej. Masz etat, ubezpieczenie. A tak to albo zakładasz swoją firmę i sama becalujesz co miesiąc, żeby 
te wszystkie świadczenia mieć, a to kosztuje i na to też trzeba zarobić, albo jesteś nieubezpieczona. [IDI-

\section{_A_D_TEATR_RDZEŃ]}

Plany na przyszłość... Słuchaj. Póki co plan jest taki, żeby jednak nie utonąć. Za miesiąc od dzisiaj muszę już być albo na rozmowach kwalifikacyjnych gdzieś, albo wręcz w podróży do Londynu czy innego miejsca, w którym za swoją pracę jestem w stanie otrzymać takie pieniądze, że po 3 miesiącach tam, mogę przez następnych 7 przeżyć w Polsce. [IDI_A_D_LITERATURA_RDZEŃ]

Artyści w bardzo ograniczonym stopniu stali się beneficjentami przemian sektora kultury. W Polsce, przy niemal całkowitym braku prywatnego systemu wsparcia, publiczne zasoby przeznaczane na kulturę $\mathrm{w}$ niewielkim jedynie stopniu trafiają do artystów (Woźniak 2013; Kurz 2019). Efekt inwestycji w kulturę widać przede wszystkim w rozwoju infrastruktury (Siechowicz, Wiśniewska, Kurek 2016). Dostępność środków nie przełożyła się jednak na poprawę sytuacji twórców. Blisko 2/3 artystów w Polsce źle ocenia skalę finansowania działań przez państwo (Ilczuk 2017). Mimo że artyści są ważnymi aktorami zmian w kulturze, nie stają się ich beneficjentami. Mają poczucie marginalizowania ich roli i braku gotowości do rozwijania strategicznego myślenia o roli artystów w procesie przemian w poszerzonym polu kultury (Szulborska-Łukaszewicz 2017). Polskie polityki kulturalne niemal całkowicie pomijają aktywną rolę artystów $\mathrm{w}$ procesach transformacji pola kultury. W dokumentach strategicznych twórcy są marginalizowani czy wręcz wprost niedostrzegani. Nie tworzy się rozwiązań, które miałyby wspierać ich działalność i ułatwiać funkcjonowanie na konkurencyjnym rynku pracy (Leśniewski 2015). Ograniczone możliwości wspierania artystów mają też instytu- cje kultury. Przez artystów często postrzegane są one jako nieprzyjazne i niesprzyjające budowaniu pozytywnych relacji współpracy (Forkert 2013). Instytucje, zajęte procesem adaptowania się do nowych warunków gry w polu kultury, borykające się z wieloma problemami i deficytami zasobów, często nie mają przygotowanych rozwiązań do pracy z artystami. Współprace bywają więc zazwyczaj skromne i doraźne, co w niewielkim stopniu odpowiada na potrzeby i oczekiwania twórców.

Do nas do instytucji przychodzi osoba, która chce coś zrobić. Przychodzi i mówi: „Czy mogę zrobić u Was wystawę?” I pierwsze co ja mówię, to: „Bardzo mi przykro, oczywiście skontaktuję cię z kierownikiem kuratorów, udzielę ci wszystkich informacji, mogę cię pokierować, ale my mamy plany na kilka lat do przodu". (...) Mamy 2 tygodnie na demontaż i wchodzi kolejna wystawa. Czasami ogłaszamy, akurat nie na wystawę, ale na warsztaty, konkurs, raz do roku. I to jest jedyna możliwość dla artystów, żeby aplikowali. [FGI_LK_INSTYTUCJA_RDZEŃ]

Częstym powodem odczuwania niepewności jest konieczność nawigowania pomiędzy artystycznym i nie-artystycznym rynkiem pracy, różnymi rolami zawodowymi, funkcjonowaniem w kontekstach, w których obowiązują różne reguły i zasady gry. Artyści są zmuszeni do adaptacji do zmieniających się warunków działania w polu kultury i przyjmowania tożsamości hybrydowej (Forkert 2013) - bycia nie tylko artystami, ale też menedżerami, producentami i edukatorami. Konieczność odnajdywania się w sytuacjach stykowych i funkcjonowania „pomiędzy” powoduje, że artyści muszą zadać sobie pytanie o sposób zarządzania własnymi karierami i projektem „ja”. Muszą stać się bardziej refleksyjni myśląc o sobie jako o artystach i poszukując pewnych punktów odniesienia, 
tożsamościowych kotwic, które dadzą im poczucie ontologicznego bezpieczeństwa (Giddens 1991).

W tej chwili jest taki moment, że biorę udział w kilku projektach naraz i to powoduje, że żyjesz bezpiecznie, ale sam fakt, że trzeba wziąć udział w kilku projektach, pokazuje, jakie to jest zwiewne. Że jeden projekt to jest za mało. (...) Można co najwyżej przetrwać. I to jest bardzo zmienne, bo dzisiaj mam te projekty, a jeszcze przed chwilą mój najważniejszy pracodawca był w kryzysie. Niech to będzie przykładem zmienności tego rynku. Dodatkowo, to drugi rodzaj działalności, to nauczanie na różnych polach: na Akademii, w galerii. Wielu z nas, nie wszyscy, bo niektórzy wybierają inne drogi, zajmują się edukacją i nauczaniem, co ma niebagatelny wpływ na bezpieczeństwo materialne. Animatorzy w Warszawie (...) stawiają na taką zupełną komercję, czym zdarzało mi się również zajmować, ale niezwykle rzadko: praca w reklamie. Spełniamy się zawodowo, realizujemy się w tym rzemiośle, ale to są rzeczy ewidentnie robione na zamówienie. Pracujemy dla totalnie komercyjnych, cudzych idei i przy okazji możemy sobie pozwolić na bardziej swobodne realizacje, które, powiedzmy, można nazwać artystycznymi. [IDI_A_D_FILM_DOM]

Sytuację niepewności wzmacnia obecne w świecie społecznym artystów poczucie obcości i niezrozumienia. Artyści często rekrutują się spośród przedstawicieli klasy średniej, wyposażonej w ponadprzeciętny zasób kapitału kulturowego. O ile względnie łatwo jest tworzyć dzieła dla ograniczonego grona ekspertów z wysoką pozycją społeczną, doświadczonych konsumentów oferty kulturalnej i częstych gości tradycyjnych instytucji kultury (Belfiore 2002), trudniej jest trafiać z ofertą dla osób, które nie mają takich zasobów i nie charakteryzuje ich tak wysoki poziom kulturalnych motywacji i aspiracji. Dla szerokiego grona odbiorców artyści mają ofertę, która relatywnie często bywa postrzegana jako niezrozumiała i nieatrakcyjna. Próbując działać w lokalnych społecznościach, twórcy mogą być postrzegani jako obcy, którzy nie rozumieją potrzeb osób, do których kierują artystyczną interwencję (Kowalewski, Nowak, Thurow 2015; Drozdowski 2017). Przez to też ich działanie może być nieskuteczne, oni sami zaś silniej odczuwają poczucie niepewności.

Z uwagi na kumulację niekorzystnych uwarunkowań prowadzenia działalności artystycznej doświadczaniu niepewności w wielu przypadkach towarzyszy poczucie bezsilności i braku wiary w możliwość zmiany istniejącego stanu rzeczy. Bycie artystą ma więc często charakter bolesnego zmagania się z rzeczywistością, a dominującą strategią jest orientacja na przetrwanie ${ }^{2}$. Problematyczne jest przy tym defetystyczne przekonanie o braku możliwości zmiany status quo (Krajewski, Schmidt 2018). Nie oznacza to jednak, że artyści nie szukają alternatywnych sposobów na zarządzanie własnymi karierami. Należy jednak pamiętać, że sytuacja permanentnego deficytu czy braku zasobów, z którą mierzą się twórcy, determinuje wybór defensywnych sposobów radzenia sobie $\mathrm{w}$ polu kultury.

\section{Wyzwanie: przekuć niepewność w sukces}

Kluczowym uwarunkowaniem działalności artystycznej w poszerzonym polu kultury jest poddawanie tych praktyk rosnącym presjom ekonomizacji i instrumentalizacji. Procesy te do pewnego stopnia zawsze wyznaczały rytm działalności artystycznej twórców (Hauser 1974; Heinich 2007).

\footnotetext{
2 Jak wynika z badań prowadzonych w grupie muzyków niezależnych, ponad $2 / 3$ z nich odczuwa stany lękowe i depresyjne, połowa czuje się samotnie, a 1/3 doświadcza napadów paniki. Zob.: https://www.the73percent.com/ [dostęp 15.08.2019].
} 
Współcześnie jednak dążenie do tego, by kultura stawała się „przydatna” i „potrzebna”, staje się szczególnie silne (Belfiore 2002; Platman 2004). Istnieje coraz wyraźniej artykułowane oczekiwanie, że artyści zaadaptują się do zmieniających się reguł gry i zajmą pozycje, na których będą mogli wykorzystać swoją wyobraźnię, kompetencję i doświadczenie w służbie celów pozakulturowych. W konsekwencji twórcy stają w rozkroku: między przywiązaniem do autonomicznego świata sztuki, w którym panują zasady autoteliczności i wolności artystycznej, a realiami, w których dominuje orientacja na pragmatyzm i kreatywność (Rokicka, Kruczkowska 2013).

Proces utowarowienia i instrumentalizacji zawodów artystycznych przyczynia się do zacierania się granic między sektorami. Artysta zbliża się - w swoim zasobie doświadczeń, palecie stosowanych narzędzi pracy i formach świadczonych na rynku usług - do reprezentantów innych branż i światów pracy. Dzieje się to równolegle z kulturalizacją innych sektorów niż sektor kultury. W następstwie tej ewolucji dochodzi do funkcjonalnego zbliżenia pozornie być może odległych od siebie światów, a symboliczny dystans między nimi słabnie. Dla artystów oznacza to wyzwanie związane z poszukiwaniem własnego miejsca nie tylko w (poszerzonym) polu kultury, ale też na styku tego i innych pól. Problematyczny charakter ma tu zresztą próba wyznaczenia granicy ustalenia, gdzie dane pole się „kończy”. Wydaje się, że granice pól są przepuszczalne i rozciągliwe, a od artystów oczekuje się, że w tych warunkach będą w stanie się odnaleźć, potwierdzając tym samym swoją społeczną wartość i użyteczność (Bridgstock 2013).

Artyści w różny sposób starają się odpowiedzieć na oczekiwanie związane $\mathrm{z}$ ich repozycjonowa- niem w polu kultury. Większość twórców na swój sposób próbuje się zaadaptować do uwarunkowań i wyzwań, jakie przed nimi stają, przede wszystkim $\mathrm{w}$ celu redukowania niekomfortowego doświadczenia niepewności (Krajewski, Schmidt 2018). W tym kontekście ciekawym procesem są zmiany w systemie szkolnictwa wyższego. Uczelnie artystyczne próbują odpowiadać na dostrzegane zapotrzebowanie oferty "praktycznej”, oferując studentom kursy ułatwiające im odnalezienie się po studiach na rynku pracy. Autorzy raportu o losach zawodowych absolwentów polskich uczelni artystycznych piszą, że zwiększenie nacisku na rozwój obszarów kształcenia takich jak promocja wizerunku czy autoprezentacja ma pomóc zmniejszyć odsetek absolwentów pozostających bez stałego źródła utrzymania. W raporcie znajdują się rekomendacje związane $z$ budowaniem sieci partnerstw z pracodawcami, rozwijaniem współpracy projektowej, przygotowywaniem absolwentów do konkurowania na rynku międzynarodowym czy rozwijaniem „umiejętności związanych z zarządzeniem i przedsiębiorczością". We wnioskach z badań znajdują się też wskazania, że nabywania tego rodzaju kompetencji oczekują sami studenci (Bogacz-Wojtanowska i in. 2015). Później o ich potrzebie mówią również już „dorośli” artyści (Kaczmarek, Posłuszna 2019). Warto przy tym podkreślić, że efektem ubocznym nowych formuł dydaktycznych, jakie oferuje się młodym artystom, jest wzrost poziomu ich oczekiwań względem przyszłej kariery, często nieadekwatny do realiów i ignorujący faktyczne możliwości „robienia kariery" (Walczak, Wyrzykowska, Socha 2016).

Wiara w dynamiczną karierę wiąże się z internalizacją oczekiwań, że artyści staną się świadomi wyzwań i ograniczeń zawodowych, przed którymi stają, będą intensywnie pracować nad odnalezie- 
niem swojej pozycji na płynnym rynku pracy i wykażą się kompetencjami, które okażą się przydatne w konkurencyjnych realiach późnego kapitalizmu (zob. np. Boltanski, Chiapello 2007). Wydaje się jednak, że to założenie nie tylko nie bierze pod uwage strukturalnych ograniczeń związanych z możliwością osiągania sukcesu rynkowego, ale też może osłabiać potencjał autonomii działań i praktyk artystycznych. Jest to zresztą szerszy spór o rolę i miejsce kultury i sztuki w życiu publicznym. Przechwytywanie kultury czy sztuki i wykorzystywanie jej w określonych celach (społecznych, politycznych czy gospodarczych) może prowadzić do licznych tarć i napięć, w tym niezgody na pozbawienie artystów prawa do samostanowienia i funkcjonowania w kontrze do mechanizmów i logiki wolnorynkowej (Lysgård 2013).

Dotyczy to jednak nie tylko włączania artystów $\mathrm{w}$ rytm pracy w biznesie (na przykład jako grafików, specjalistów ds. marketingu, producentów filmów) (Łuczaj 2018), ale szerzej rozumianej niezgody na oczekiwanie od artystów, że swoją aktywność poświęca oni celom społecznym - będą edukatorami, animatorami, pracownikami socjalnymi (Forkert 2013). Strukturalny przymus dopasowania się do realiów pracy „przydatnej” i „pożytecznej” budzi sprzeciw, także wśród polskich twórców. Panuje przekonanie, że projekty społeczne wymuszają na artystach wieloetatowość, multiplikację ról i „odciągają" od uprawiania sztuki, a poddanie działalności twórczej kryteriom poza-autonomicznym grozi utratą tożsamości i krytycznego potencjału własnych działań.

Tego rodzaju zagrożenia artyści lokują przede wszystkim w logice projektowo-grantowej. Z jednej strony praca $\mathrm{w}$ modelu projektowym staje się coraz bardziej powszechna, z drugiej - w wyraźny sposób ogranicza autonomię artystyczną, zwiększa poziom niepewności i wymusza dopasowanie się do wymagających zasad gry rynkowej. Poza tym system projektów i grantów wyraźnie wspiera osoby młode, rozumiejące specyficzny kod i język celów, środków i efektów, często będące specyficzną grupą docelową („młodzi artyści”), do której kierowane jest wsparcie (Bachórz, Stachura 2015a; Krajewski, Schmidt 2018). Idea projektu wzmaga konkurencyjność w środowiskach artystycznych i promuje określone formuły działań kulturalnych, $\mathrm{z}$ eventami na czele. Łączy tym samym sprzeczne na pozór logiki sztuki i biurokracji, oswajając potencjalnie antysystemowe treści artystyczne i pozbawiając je ich pierwotnego znaczenia. Równolegle dochodzi do standaryzacji i zglajszachtowania aktywności twórczej, a artysta, pod wpływem fali przemian, z geniusza i szaleńca musi przeistoczyć się w kontrolującego emocje menedżera (Możdżyński 2018).

A może jest tak, że niekoniecznie ci, którzy piszą dobre granty, robią dobrą sztukę. (...) Ja sama mam menadżera, ale póki co sama piszę granty, ponieważ się tego sama nauczyłam. I wypełnianie tych rubryczek jest straszne. Ja jestem chora, ale robię to. Czasami nie robię, bo stwierdzam, że wolę to przedstawienie zrobić za swoje pieniądze, bo nie będzie mnie to aż tyle kosztować. (...) Ja mogę jeszcze napisać grant, bo to mi przystoi, ale jak ja mam jechać na konkurs choreograficzny czy taneczny, to błagam. [FGI_A_D_TANIEC_RDZEŃ]

Menedżer dba z kolei przede wszystkim o to, żeby projekt został sprawnie przeprowadzony i rozliczony, mniejszą uwagę przywiązując do merytorycznej zawartości działania artystycznego. Dodatkowo „bycie w projekcie” redukuje doświadczaną niepewność właściwie tylko na chwilę. Po zakoń- 
czeniu danego przedsięwzięcia twórca będzie bowiem prawdopodobnie poszukiwał alternatywnych możliwości zarobkowania czy podjęcia pracy. Jeśli na dłużej zdecyduje się na pozostanie w sferze projektowo-grantowej, w pewnym momencie natrafi na inną trudność, czyli radykalne skrócenie perspektywy czasowej, w której zakorzenione jest prowadzone przez niego działanie. Projekty sprawiają bowiem, że liczy się kontekst krótkoterminowy i osiągnięcia widoczne $\mathrm{w}$ danym momencie (Kozłowski, Sowa, Szreder 2014b). W tak nakreślonych realiach trudne jest zarówno osiągnięcie sukcesu (bo konkurencja o środki grantowe jest duża), jeszcze trudniejsze zaś - jego utrzymanie (czyli realizowanie kolejnych projektów i uczestnictwo w kolejnych grantach).

Strategią nakierowaną na redukowanie niepewności i jednoczesne zbliżanie się do sukcesu (który rozumiem tu przede wszystkim jako zestaw określonych osiągnięć, dostęp do zasobów oraz widzialność i rozpoznawalność środowiskową) jest dążenie do stania się "przedsiębiorcą samego siebie" (Foucault 2011). Ta typowa dla późnego kapitalizmu figura wyposaża artystów w poczucie podmiotowości $\mathrm{w}$ drodze akceptowania sprywatyzowanego modelu kariery zawodowej, aprobaty dla „przydatności” artystów w życiu publicznym i zgody na projektowe reguły gry. Neoliberalny reżim karier artystycznych staje się głównym punktem odniesienia w planowaniu własnych losów zawodowych i prowadzi do internalizacji przekonania o znaczeniu indywidualnej zaradności i sprawstwa (Hughes i in. 2013; Allen 2014). Menedżerska narracja indywidualnej samorealizacji ma stanowić antidotum na trudności adaptacyjne do realiów poszerzonego pola kultury (Bachórz, Stachura 2015a; Szreder 2018). Minimalizuje się za to lub wprost nie dostrzega znaczenia czynników strukturalnych w modelowaniu karier twórców (Abbing 2002; Bendassolli, Wood Jr. 2012).

Umiejętność samodzielnej nawigacji w polu kultury przybiera $w$ praktyce postać stale rozwijanej skrzynki prac i projektów. Za naturalny element bycia przedsiębiorcą samego siebie uważa się łączenie pracy artystycznej z „normalną” pracą poza sektorem kultury, nabywanie nowych typów umiejętności i poszukiwanie nowych ról zawodowych. Tożsamość kariery artystycznej staje się płynna i elastyczna, a twórca, by zwiększyć swoje szanse na sukces, musi pozostawać skoncentrowany i czekać na nadarzające się okazje (Bridgstock 2013). Artyści dążą więc do tego, by być sprawnymi, efektywnymi administratorami własnych karier, balansując między sektorem publicznym i prywatnym, etatem i projektem, budowaniem własnego wizerunku i uprawianiem sztuki. Im bardziej konkurencyjny jest dany subświat społeczny, w którym zakorzenieni są twórcy, tym więcej czasu trzeba poświęcić na proces zarządzania ,ja” (Forkert 2013). Czas wolny zostaje w ten sposób skolonizowany przez czas pracy - życie osobiste i zawodowe przenikają się, a ich granice są trudne do wyznaczenia (Możdżyński 2018).

Jest taka strona dla artystów, Behance, gdzie są różne portfolia, (...) no to tam wyszukałam artystów i projektantów, którzy mieszkają w X [nazwa innego kraju, gdzie rozmówczyni planowała wyjechać - przyp. KS] i napisałam do nich. Zapytałam się, czy mogą polecić miejsce, gdzie można zrobić wystawę. Napisałam chyba 50 wiadomości, z czego dostałam 25 odpowiedzi, z czego na 5 odpowiedzi rzeczywiście ktoś powiedział, gdzie można zrobić wystawę. No to napisałam do tych miejsc, z czego jedno miejsce odpowiedziało, że mogę mieć tę wystawę bezpłatnie. (...) Ambasada polska też wydrukowała plakaty i ulotki, też zaprosili 
swoich gości. Ja zaprosiłam tych projektantów i artystów z Behance'a, którzy do mnie napisali, ale też do innych napisałam, że mogą przyjść. (...) Pomyślałam sobie, że nikt nie przyjdzie, ale wszyscy, okazało się, się pospóźniali. Po godzinie było już jakieś 50, 60 ludzi, gdzie nikogo w mieście tak naprawdę wcześniej nie znałam. (...) Było może ciężko, były jakieś kamienie po drodze, ale się udało. [IDI_A_ND_WIZUALNE_RDZEŃ]

\section{Jak zwiększyć swoje szanse na sukces?}

W konkurencyjnym świecie społecznym artystów istnieje szereg czynników, które warunkują prawdopodobieństwo osiągania sukcesu. Ponownie utożsamiam tu sukces $\mathrm{z}$ jednej strony $\mathrm{z}$ reputacją, jaką cieszą się zarówno artyści, jak i ich dzieła (Becker 2008), z drugiej - z osiągnięciami, możliwością zajmowania centralnych pozycji w polu, a także środowiskowym uznaniem i widzialnością. Przykładam więc do sukcesu miarę pewnych „obiektywnych" kryteriów, które osobie spoza świata artystycznego mogą wydawać się istotne. $\mathrm{W}$ rzeczywistości, o czym piszę $\mathrm{w}$ dalszej części tekstu, sposoby definiowania sukcesu wśród artystów mogą być inne.

Niezależnie od tych różnic wyróżnić można kilka obszarów mających znaczenie z punktu widzenia zarządzania karierami przez twórców. Istotne $\mathrm{w}$ tym kontekście są kwestie związane $\mathrm{z}$ talentem i kompetencjami, jakie posiadają artyści (zob. np. Pinheiro, Dowd 2009), a także skalą wewnętrznej motywacji do uprawiania działalności artystycznej. Z badań polskich muzyków wynika, że blisko 9 na 10 wybrało artystyczną drogę zawodową ze względu na pasję (Walczak, Wyrzykowska, Socha 2016). Motywacja, talent czy wyuczone umiejętności są podstawą budowania swojej pozy- cji w świecie artystycznym, a ich znaczenie jako czynników generujących potencjalny sukces jest niepodważalne (Bachórz, Stachura 2015a). Istotną rolę w stawaniu się uznanym artystą pełni też odpowiednia trajektoria socjalizacyjna. Młodzi artyści doświadczają udanego przejścia z adeptów w dojrzałych twórców dzięki wsparciu rodziców (na przykład finansowaniu lekcji prowadzonych przez prywatnych nauczycieli) i dobrym warunkom dojrzewania w okresie dzieciństwa i młodości (Burland, Davidson 2002; Gladwell 2008; Pinheiro, Dowd 2009).

W poszerzonym polu kultury osiąganiu sukcesu sprzyja także gotowość do internalizacji dyskursu o przydatności twórczości artystycznej i konieczności stawania się przez twórców przedsiębiorcami samych siebie. Przyjęcie za wiążące menedżerskiego stylu zarządzania karierą artystyczną sprawia, że artyści biorą sprawy we własne ręce. Podejmują starania o to, by osiągnąć sukces, bazując przede wszystkim na zasobach wewnętrznych, nie zaś uwarunkowaniach zewnętrznych (Baczko-Dombi, Wysmułek 2014). W książce poświęconej budowaniu pomyślnych karier muzycznych Angela Myles Beeching - na co dzień specjalizująca się we wspieraniu artystów w procesie zarządzania ich karierami - (2010) rekomenduje, by artyści aktywni promowali siebie i swoją twórczość, zyskiwali przekonanie o własnym sprawstwie i stawali się „architektami swojej przyszłości”. Talent i ciężka praca są konieczne, ale nie wystarczą do tego, by odnieść sukces, pisze Beeching, dodając, że artysta może wyróżnić się spośród innych, jeśli będzie szczególnie zmotywowany, skoncentrowany na osiąganiu celów i odporny na porażki. Powinien posiadać, niczym zawodowy sportowiec, instynkt zwycięzcy, który zaraża innych entuzjazmem. Dzięki niemu radzi sobie z porażkami, 
umie aktywnie wypoczywać (by być następnie bardziej produktywnym i efektywnym), rozbudowuje własną sieć kontaktów, a przede wszystkim ma opracowaną strategię rozwoju, którą konsekwentnie wdraża i na bieżąco ewaluuje oraz modyfikuje (Battenfield 2009; Beeching 2010).

Ostatnio był taki moment, że zastanawiałam się nad różnymi kwestiami. Pożegnałam się z moją poprzednią szkołą i przez jakiś czas byłam bezrobotna. Zastanawiałam się właśnie, gdzie podjąć pracę. I wtedy sobie pomyślałam, że najbardziej lubię prowadzić warsztaty teatralne, jednak i tych ofert mam całą masę. I wszędzie właściwie, gdzie się nie zgłosiłam, to ludzie z otwartymi ramionami zapraszali do współpracy. A potrafię też się sprzedać. Jestem straszliwie przebojowa, przedsiębiorcza, no i chyba po prostu taki mój los jest. (...) Nie boję się, po prostu wiem, że w każdej sytuacji sobie poradzę. Jak będę chciała, to wiem, że nie ma dla mnie żadnej granicy, już wiem to. Właściwie cokolwiek bym sobie wymyśliła, to jestem $w$ stanie to zrealizować. (...) Z czego to wynika? Myślę, że to wynika z mojego nastawienia do pracy. Jeżeli ktoś mnie poznaje i widzi, jak ja pracuję, z jakim zaangażowaniem, pasją, energią, talentem, to poleca mnie dalej. I to się tak ciągnie. I jak mnie już poznaje, to nie chce mnie puścić. Dalej chce ze mną współpracować. Ja wiem, że to może trochę nieskromne, ale ja nie należę do skromnych osób. [IDI_A_D_TEATR_ MOM]

Innym elementem, który artyści powinni opanować, jeśli chcą zwiększyć swoją szansę na sukces, jest umiejętność poruszania się w polu kultury (Bourdieu 1993; 1996) i obecność w miejscach, w których spotykają się kluczowi aktorzy dysponujący ważnymi zasobami (Zolberg 2015). Artyści nie tylko nie powinni czekać na to, aż ktoś ich odkryje (Grant 2010), ale też, porzuciwszy romantyczne wyobrażenia o świecie artystycznym, dbać o kluczowy z punktu widzenia dynamiki kariery twórczej kapitał społeczny. W poszerzonym polu kultury kapitał symboliczny sztuki dla sztuki pozostaje ważny, ale ranga kapitału społecznego w sposób dynamiczny wzrasta (zob. np. Mulkay, Chaplin 1982). Nie jest on już podrzędny w stosunku do rangi merytorycznej twórczości czy takich cech jak talent i kompetencja artystyczna. Kapitał społeczny zdobywa się dzięki cyrkulacji, widoczności, autopromocji i umiejętności odnajdywania się w odpowiednim miejscu w odpowiednim czasie (Giuffre 1999). Bez bycia dostrzeżonym możliwość osiągania sukcesu w sposób drastyczny spada. Kryterium oceny są nie stare karty artystycznego portfolio, ale jakość ostatniego realizowanego projektu (Kozłowski, Sowa, Szreder 2014b).

Na pewno są jakieś środowiska malarzy w Trójmieście, jakoś się grupują. My też tworzymy jakąś tam społeczność muzyków. To jest jakieś tam środowisko. (...) W grupie łatwiej się obronić albo narzucić jakieś swoje reguły innym. Przecież ZAIKS to jest stowarzyszenie, grupa twórców i rządzą. Są nazywani mafią, ale to naturalny proces, że ludzie się łączą w grupy i walczą o swoje prawa. (...) Musisz się zintegrować albo się wbić do jakiejś ekipy. Zaprzyjaźnić się z jakąś bandą. Dołączyć do gangu albo stworzyć swój gang. [IDI_A_D_MUZYKA_RDZEŃ]

W polu toczy się więc coraz bardziej intensywna walka o dostęp do jego kluczowych pozycji. Ich osiągnięcie zależne jest jednak od wyjściowego stanu posiadania. Zgodnie z zasadą kumulatywnych korzyści im więcej kapitałów twórca posiada na starcie, tym bardziej prawdopodobne jest, że będzie akumulował ich coraz więcej także później (Merton 1968). Przedsiębiorczy (w stosunku do samych siebie) artyści znajdują się w sytuacji 
trudnej - z jednej strony są skazani na współpracę, szukanie partnerów projektowych i funkcjonowanie $\mathrm{w}$ różnych sieciach kontaktów, z drugiej jednak są przede wszystkim odpowiedzialni sami za siebie i postawieni przed wyzwaniem budowania własnej ścieżki kariery. Wydaje się, że w modelu koopetycji, w którym jednocześnie trzeba współpracować i konkurować, dominująca będzie, mimo wszystko, presja na konflikt i walkę w celu zapewnienia sobie dostępu do nowych szans i możliwości, osłabnie natomiast środowiskowa solidarność (Szreder 2018).

\section{Sukces jako problem, sukces jako proces}

Kategoria sukcesu ma wśród artystów nieoczywisty i niejednoznaczny wydźwięk. „Problem z sukcesem" wynika z kilku czynników, przede wszystkim z przemian w środowisku artystycznym i w składzie poszerzonego pola kultury, niepewności związanej z funkcjonowaniem artystów w życiu publicznym oraz wątpliwości, jakie wiążą się ze społecznym odbiorem twórczości. Istnieje też wyraźny rozdźwięk między potencjałami, możliwościami i obietnicami osiągania sukcesu a realiami życia codziennego twórców. Z jednej strony bowiem artystów przekonuje się do tego, by zostawali przedsiębiorcami samych siebie i odważnie konfrontowali się z logiką świata sztuki (wszystko to po to, by móc uzyskać wysoką pozycję społeczną oraz cieszyć się rozpoznawalnością i uznaniem), z drugiej natomiast twórcom brakuje wielu typów zasobów (finansowych, czasowych, logistycznych i nie tylko), by pewne zewnętrzne kryteria sukcesu osiągać.

Inkluzywna definicja artysty i świata artystycznego umożliwia dostrzeżenie perspektywy „zwykłych artystów”, tych, którzy nie są predestyno- wani do osiągania wielkiej popularności, którzy często nie mogą utrzymać się z uprawiania sztuki, którzy w swojej twórczości są „zwyczajni”, a przez to też niedostrzegani. W tym i kolejnym fragmencie tekstu relacjonuję perspektywę artystów mieszkających na co dzień na terenie województwa pomorskiego. Część z nich żyje i pracuje w rdzeniu metropolii, czyli w Trójmieście, część ogniskuje aktywność życiową poza nim, także w małych miejscowościach na peryferiach regionu. To usytuowanie geograficzne ma kluczowe znaczenie z punktu widzenia myślenia i mówienia o sukcesie, przede wszystkim sposobach jego rozumienia i osiągania. W obu przypadkach, zarówno gdy mowa o zamieszkiwaniu w Trójmieście, jak i poza nim, mamy do czynienia z różnymi wymiarami peryferyjności, które nie pozostają bez wpływu na pozycję artystów w polu i strategie budowania karier i osiągania sukcesu.

Sukces jest kategorią, od której wielu twórców się dystansuje. Rozumienie sukcesu ma nieostre kryteria i jest indywidualizowane, to znaczy zakłada się, że każdy może definiować sukces na swój własny sposób, w zależności od modelu uprawiania działalności artystycznej i oczekiwań, jakie ma się wobec własnej kariery. W narracjach o sukcesie wyraźnie pobrzmiewa ton wątpliwości. Dotyczy ona tego, co na temat osiągnięć danego artysty mówią inni (rodzina, publiczność, krytycy), jak artysta wypada na tle innych i co to właściwie znaczy, że ktoś „osiąga sukces”.

Są różne sukcesy. Ja mogę powiedzieć, czym jest dla mnie. (...) Nie ma jednego znaczenia sukcesu, bo wszystko zależy od tego, jak, kto i co pisze. Zależy, kto cię odkryje i co będzie ważne. (...) Nie ma takiej definicji sukcesu. Najważniejsze jest dla mnie teraz, aby tworzyć świadomie i się uczyć. (...) Nie ma reguł, 
że ktoś wypłynie, a ktoś nie. (...) Sukces nie ma logiki, ciężko go skonkretyzować. (...) W tym zawodzie nie ma takiego poczucia. Co to znaczy? Wtedy przestajesz tworzyć. A tworzysz, bo poszukujesz. [IDI_A_D_WIZUALNE_RDZEŃ]

Sukces ma też różną rangę. Małe sukcesy mogą być przeplatane długimi okresami stagnacji czy serią porażek, sukces w jednej grupie odniesienia nie jest równoznaczny $\mathrm{z}$ uznaniem $\mathrm{w}$ innym gronie, a sukcesy własne mogą stać w cieniu sukcesów innych twórców. Sukces jest też tymczasowy, bywa niedostrzegany i pomijany, postrzega się go w kategoriach czegoś, co trudno przekuć w kolejne artystyczne szanse czy konkretne (symboliczne i materialne) zyski. Ten rodzaj narracji, w której twórcy dystansują się od znaczeń, jakie przypisuje się sukcesowi, wpisuje się w niepokoje neoliberalnej logiki trajektorii artystycznych, w ramach której poziom konkurencji między aktorami jest bardzo duży, kariery są krótkie i obowiązuje zasada, że "zwycięzca bierze wszystko" (Forkert 2013).

Zapewne między innymi z tego powodu wielu artystów pomniejsza znaczenie sukcesu komercyjnego. W sytuacji, gdy uprawianie działalności artystycznej nie jest $\mathrm{w}$ stanie przynosić dochodu na tyle dużego, by utrzymywać się wyłącznie z podejmowania tego rodzaju aktywności, jako istotniejsze wyróżnia się pozamaterialne wymiary sukcesu. Pieniądze mogą wówczas pełnić funkcję dodatkowego zysku z poświęcenia się twórczości, ale nie mogą być głównym bodźcem i motywatorem do funkcjonowania w świecie społecznym artystów (Bachórz, Stachura 2015a; Krajewski, Schmidt 2018). Dystansowanie się od materialnych uwarunkowań osiągania sukcesu jest też oznaką braku zgody na pozbawienie twórców autonomii.
Gdy nie muszą oni intensywnie dążyć do zaspokajania poprzez twórczość potrzeb finansowych, są w stanie zachować niezależność i pracować zgodnie z własnym imperatywem artystycznym.

Pamiętam, jak zespół Myslovitz był z nami na próbie. Oni zaczynali wtedy. My zazdrościliśmy im sukcesu, a oni nam wolności tworzenia. I teraz tak. Ja mógłbym zazdrościć Rojkowi sukcesu OFF Festivalu. Że jest biznes, że się kręci, że jest zajebisty festiwal. Ale on może zazdrościć mi X [nazwa wydarzenia zainicjowanego przez rozmówcę - przyp. KS], gdzie jest totalna wolność i wszyscy są szczęśliwi. Albo warsztatów z M. [nazwisko uznanego artysty niezależnego - przyp. KS] Czaisz? A dla niego M. jest tylko kontrahentem. I tyle. [IDI_A_D_MUZYKA_RDZEŃ]

Sukces jest też postrzegany w kategoriach procesualnych. Należy wyraźnie podkreślić, że osiąganie sukcesu widziane jest jako proces bardzo nielinearny, znaczony sytuacjami kryzysowymi, a także taki, którego przebiegu nie sposób przewidzieć. Mają na to wpływ przemiany w polu kultury (w tym transformacje ról artystów), zmienny status dostępu do zasobów, ale też specyfika indywidualnych trajektorii życiowych. Proces dochodzenia do momentu, w którym artyści mogą powiedzieć, że osiągnęli sukces, najeżony jest doświadczeniem niepewności, lęku przed deklasacją i koniecznością radzenia sobie $\mathrm{z}$ nieprzewidzianymi trudnościami (Bachórz, Stachura 2015a; Wyrzykowska, Zawadzka 2018). W wyobrażeniach artystów nie jest to też sukces w takim samym znaczeniu, jaki przypisywał tej kategorii Alan Bowness (1989). Bowness uważał bowiem, że sukces artystyczny można przewidzieć, a osiąga się go w drodze zdobywania uznania kolejnych kręgów recenzenckich - grona własnego, krytyków, kupców i kolekcjonerów oraz szerokiego grona środowiska artystycz- 
nego. Jakkolwiek dla wszystkich twórców uznanie w różnych kręgach jest istotne, nie jest ono warunkiem koniecznym do tego, by w drodze określonego procesu dojść do czegoś, co artysta sam mógłby uznać za sukces.

Sukces widziany przez pryzmat procesu pozwala na docenienie drogi, jaką przechodzi artysta od momentu, gdy rozpoczyna działalność artystyczną, aż po moment, gdy decyduje się na jej zakończenie. Taka percepcja sukcesu stanowi też mechanizm obronny przed zmierzaniem do pewnego nieokreślonego bliżej punktu w przyszłości - takiego, do którego dotarcie jest trudne, i w przypadku którego gratyfikacja związana z potencjalnym osiągnięciem celu zostaje na długo odroczona. Równolegle utożsamianie sukcesu z ciągłym aktem twórczym minimalizuje rangę punktowych osiągnięć - spektakularnych projektów, w których bierze się udział, otrzymywanych nagród, momentów chwały i zwycięstw. Z uwagi na to, że stanowią one "paliwo" działalności twórczej na krótki okres, racjonalna wydaje się strategia konsekwentnego zaangażowania w działalność twórczą, niezależnie od korzyści czy uznania, jakie się z jej podejmowaniem wiążą. Sukces przez duże $S$ może poza tym onieśmielać i wyzwalać dodatkowe oczekiwania, których artysta nie będzie w stanie spełnić (przed samym sobą i przed innymi).

Zaraz po studiach uczestniczyłem w wystawach. Dałem swoje obrazki na taki festiwal, dzisiaj to rzadko się odbywa, i, proszę Pana, gdzieś spacerowałem potem nad Motławą i spotkałem z naszego środowiska kolegę, który mówi: „Czy Ty wiesz, że dostałeś nagrodę?". I wtedy, pamiętam, jak oblał mnie zimny pot i ciemno mi się przed oczami zrobiło. Tak się przeraziłem pozytywnie. Nie powiedziałem słowa w ogóle. Ale żebym nazwał to sukces? To był jakiś sukces przecież, wiadomo, nie każdy otrzymuje nagrodę. To było wrażenie niesamowite. Ale to wcale nie świadczyło potem w konsekwencji, że ja więcej pracowałem, że mnie to zmobilizowało do roboty. Nie. To mnie zahamowało i bardzo przeżyłem to. To wszystko, potem $\mathrm{w}$ trakcie pracy... Lata mijały, często dostawałem jakąś nagrodę czy wyróżnienie, ale to nie robiło już na mnie wrażenia takiego, że mnie to jakoś uszczęśliwiało i stawiało na piedestale. (...) Niczego to nie uczyniło, żebym z tego tytułu stał się bogatszy, ważniejszy i cholera wie co. [IDI_A_D_WIZUALNE_RDZEŃ]

Taki gotowy sukces sprawia, że ludziom totalnie odbija i popadają w różne stany. No nie samobójcze, ale spójrzmy na historię ogólnie popkultury. Koledzy Beatlesi rozwiązali się w najlepszym momencie swojej sławy, kolega Jim Morrison odszedł z zespołu w momencie, kiedy Doorsi byli na mega topie światowym. Idąc dalej, nawet Guns'n'Roses rozwiązało się w swoim najlepszym momencie. (...) To się może zdarzyć wszystkim ludziom, którzy mają, jak to nazwać, słabe nerwy. W tej branży, w każdej branży zresztą, trzeba radzić sobie świetnie zarówno z brakiem sukcesu, jak i z samym sukcesem. Bo mam na przykład kolegów, którzy jako zespół bardzo dobrze funkcjonowali na jakimś standardowym poziomie. Zabił ich sukces. Zaczęły się kłótnie w zespole, zaczęły się jakieś ambicjonalne rozgrywki. Bieda ich łączyła i zwierała szeregi, a sukces ustawił każdego w innym kierunku. No i wiesz, nie wszyscy wytrzymują to ciśnienie. [IDI_A_D_LITERATURA_RDZEŃ]

\section{Pragmatyczna strategia zmagania się z sukcesem}

Problematyzowanie i dystansowanie się od kategorii sukcesu, a w części także postrzeganie sukcesu przez pryzmat procesu, dowodzą tego, że wielu artystów przyjmuje defensywno-kompensacyjną 
strategię zarządzania sukcesem. Jest to o tyle zaskakujące, że oczekiwania formułowane względem artystów są inne. W logice późnego kapitalizmu sugeruje im się rozwijanie postaw przedsiębiorczych, dynamiczne i sprawcze poszukiwanie nowych dróg i wyzwań zawodowych, odważne zmaganie się ze światem grantów, projektów i eventów. Tą drogą podążają nieliczni twórcy. Odpowiedzią większości artystów jest zastosowanie strategii bardziej ostrożnej, takiej, w której nawet jeśli podejmują oni próby wchodzenia na ścieżkę dynamicznego zarządzania własnymi trajektoriami zawodowymi, to zasadniczą wagę przywiązują przede wszystkim do dopasowywania posiadanych zasobów i potencjałów do realiów, w jakich są zakotwiczeni. Można postrzegać ten rodzaj strategii adaptacyjnej jako minimalistyczny czy wycofany, ale jest on też efektem pragmatycznej kalkulacji: co jest możliwe, jakie szanse są w zasięgu i na podjęcie jakich ryzyk można próbować się decydować.

Być może ta pragmatyczna strategia jest nie tylko pochodną trudności $\mathrm{w}$ adaptacji do poszerzonego pola kultury czy odpowiedzią na strukturalną niepewność zainstalowaną w logice świata artystycznego. Te czynniki zdają się uniwersalnymi wyzwaniami dla artystów w skali całego sektora państw rozwiniętych. W Polsce bardzo wysoki jest jednak także wskaźnik skłonności do unikania ryzyka. W rankingu 66 państw z całego świata Polska znajduje się na 7. miejscu, jeśli chodzi o wartość tego wskaźnika. Jest ona też znacząco wyższa od średniej dla wszystkich krajów (świat - 65, Polska - 93). Skłonność do unikania ryzyka przejawia się w odczuwaniu dyskomfortu związanego z okolicznościami, które są nowe, nietypowe i zaskakujące ${ }^{3}$.

${ }^{3}$ Uncertainty avoidance [dostęp 15.08.2019]. Dostępny w Internecie: 〈https://clearlycultural.com/geert-hofstede-cultural-dimensions/uncertainty-avoidance-index/>.
Ta cecha polskiej kultury narodowej mogłaby więc w pewnym stopniu wyjaśniać specyficzne dla środowiska artystycznego manifestacje defensywno-kompensacyjnej orientacji na sukces. Najnowsza historia Polski wyjaśnia w znacznym stopniu dystans, by nie powiedzieć niechęć, względem kategorii sukcesu (Gładys-Jakóbik, Książkiewicz 2005; Łazarowicz-Kowalik 2015). W okresie Polski Ludowej sukces kojarzony był z narzucaną centralnie propagandą (Grzeszczyk 2003). Wzór człowieka sukcesu zgodny z ideologią indywidualistyczną, typową dla systemów kapitalistycznych, rozpowszechnia się w Polsce wraz z nastaniem transformacji ustrojowej, a orientacja na osiąganie sukcesu, charakterystyczna dla klasy średniej w społeczeństwach Europy Zachodniej, ma relatywnie krótką historię trwania (Domański 2012).

Przejawem orientacji defensywno-kompensacyjnej jest minimalistyczne postrzeganie sukcesu artystycznego. W takiej perspektywie sukcesem jest już na przykład sam fakt utrzymywania się z tytułu prowadzenia działalności artystycznej czy doświadczania indywidualnego spełnienia, jakie jest pochodną bycia aktywnym twórcą. Wartościowy jest sukces osobisty wynikający z tego, że jest się artystą, uprawianie sztuki na własnych zasadach, poczucie spełnienia i samorealizacji (Krajewski, Schmidt 2018), jakie wiążą się z tym, że można tworzyć i zainteresować swoimi dziełami innych. Niektórym artystom wystarcza przy tym to, że ich sztuka sama się finansuje. Nie dotyczy to tylko twórców-amatorów, ale też osób, które pracują w sektorze kultury, część swojej aktywności zawodowej traktując jako praktykę nieobliczoną na pozyskiwanie dochodu.

Ja, w związku z tym, że długo pracowałam na miejsce, w którym jestem, musiałam się szybko nauczyć, 
że mój sukces nie zależy od warunków zewnętrznych. To znaczy, że bez względu na to, czy dostanę nagrodę, czy nie, to sama muszę sobie sformułować, na czym to dla mnie polega. (...) To, jak to później będzie odebrane przez ludzi z zewnątrz, czy publiczność zwykłą, czy krytyków, jako coś wartościowego, to to jest dla mnie takie wtórne, nie aż tak ważne. [FGI_A_D_TANIEC_RDZEŃ]

Silna wewnętrzna motywacja, poczucie pasji, ale i ucieczka przed ryzykiem i chęć redukowania niepewności sprawiają, że poczucie zadowolenia, a niekiedy i sukcesu, przychodzi bardzo szybko. Wielu artystom znacznie bardziej korzystne wydaje się zawieszenie poprzeczki z hasłem "sukces" nisko, a w efekcie jej relatywnie bezproblemowe pokonanie, niż zmaganie się z osiągnięciem bardzo dobrego wyniku, przy jednoczesnym ryzyku, że zadanie to się nie powiedzie. Można oczywiście argumentować, że taki stosunek do uprawiania sztuki jest sprzeczny z samą jej ideą - przekraczaniem granic, poszukiwaniem nowych rozwiązań estetycznych czy poruszaniem emocji odbiorców a samym artystom nie gwarantuje "prawdziwego sukcesu" (dużej rozpoznawalności, wysokiej jakości dzieł czy dostępu do cennych zasobów), ale jest też na wskroś pragmatyczny. Pozwala zarówno na zachowanie statusu artysty, jak i na unikanie konfrontacji z sytuacjami trudnymi i doświadczaniem porażek, nieuchronnych we wprawdzie poszerzonym, ale jednak przede wszystkim bardzo konkurencyjnym polu kultury.

Można też potraktować ten rodzaj strategii adaptacyjnej jako element racjonalizacji własnej kondycji artystycznej. Innymi słowy, analizować tę strategię jako fantazmat, wyobrażeniowy scenariusz, w którym aktorzy sami definiują, co jest ich pragnieniem (realizacja powołania, satysfakcja z działa- nia) w sytuacji, w której na przykład nie otrzymują wynagrodzenia za swoją pracę lub ich aktywność artystyczna cieszy się umiarkowanym powodzeniem (Kozłowski, Sowa, Szreder 2014b). Artyści, którzy swoją działalność realizują w zgodzie z etosem inteligenckim, mogą mieć trudność ze znoszeniem konieczności adaptacji do nielubianych reguł gry poszerzonego pola kultury. Jednocześnie, historycznie przyzwyczajeni do doświadczania deficytów sukcesu materialnego (Wyrzykowska, Zawadzka 2018), zadowalają się jego substytutami - prestiżem, uznaniem wybranego grona odbiorców czy satysfakcją własną.

Dopłacam. Tak, oczywiście. Do twórczości dużo dopłacam, ale uważam, że ludzie, którzy przychodzą na te spotkania, które ja organizuję, to są moi goście. To jest tak, jak bym zaprosiła ich do swojego domu. Mam tutaj większą przestrzeń, więc mogę zaprosić zamiast dwóch, trzech osób... Mogę zaprosić 20 osób, 30. Więc cieszę się. Im więcej jest tych osób, tym bardziej się cieszę i mogę wnętrze, które dostaję, zamienić w inne wnętrze. [IDI_A_D_LITERATURA_RDZEŃ]

Zarabiałam tyle, ile potrzebowałam na swoje zachcianki. W okresie takiej wzmożonej działalności, to nawet nieźle mi szło. Ale już później, jak emeryturę dostałam, to ja już nie muszę, mi się nie chce. Już tylko dla przyjemności będę to robić. [IDI_A_ ND_WIZUALNE_DOM]

Być może najważniejszym wymiarem sukcesu $\mathrm{w}$ warunkach pracy $\mathrm{z}$ ograniczonymi zasobami jest sukces odbiorczy, rozumiany tu jako stała relacja z publicznością i możliwość otrzymywania od niej komunikatów zwrotnych. Znacznie bardziej istotne od ilościowego sukcesu (duża publiczność, liczba sprzedanych prac i tym podobne) 
jest wchodzenie w dialog z odbiorcami i poczucie realizacji misji, jaka wiąże się z dostarczaniem innym treści artystycznych. Wprawdzie za istotne uważane jest uznanie $\mathrm{w}$ eksperckich kręgach recenzenckich, trzeba mieć jednak na uwadze fakt, że jest ono trudne do osiągnięcia, a przy tym także bardziej nietrwałe. Fakt ten powoduje koncentrowanie uwagi wielu twórców na lokalnym obiegu artystycznym. W szeroko zdefiniowanym świecie społecznym twórców mitem jest powszechne dążenie do brania udziału $\mathrm{w}$ konkurencyjnym wyścigu o zasoby zlokalizowane $\mathrm{w}$ centrach (stolicy regionu, stolicy kraju, za granica). W zgodzie $\mathrm{z}$ tendencją do redukowania niepewności twórcy preferują działania w miejscach, w których mieszkają, w ośrodkach, w których widzą szansę na uznanie i rozpoznawalność. Transfer do dużego miasta dla wielu z nich byłby skokiem na zbyt głęboką wodę, decyzją niedopasowaną ani do puli posiadanych zasobów, ani do zakresu własnych kompetencji, ani deklarowanych chęci. Przesunięcie $\mathrm{w}$ bardziej gęsty obszar pola naraziłoby ich na prawdopodobną możliwość doświadczenia porażki, konieczność tkania nitek kapitału społecznego w nieznanym środowisku i utratę waloru lokalności, często pożądanego w miejscu, w którym artyści aktualnie żyją i tworzą (Bachórz, Stachura 2015a).

Sukcesem jest to, że ludzie podchodzą. No, nie muszą tego robić, ale podchodzą. (...) Kiedy widać taką szczerą wdzięczność... Głupia sprawa, podszedł do nas facet i mówi: „No, panowie, zagraliście taką zwrotkę, że nawet niektórzy nie wiedzą, że taka istnieje, no super". Ludzie doceniają takie rzeczy, na które my sami czasami nie zwracamy uwagi. Ale to jest sukces. To, że to oddziałuje na ludzi, że my gdzieś tam gramy. [IDI_A_ND_MUZYKA_MOM]

\section{Wnioski. Nowe zasady i stare przeszkody - kilka uwag o hakowaniu reguł gry w poszerzonym polu kultury}

Niejednoznaczny charakter kategorii sukcesu w świecie artystycznym powinien być, jak argumentuję w tekście, analizowany w szerszej perspektywie przemian pola kultury. Współczesnym wyzwaniem dla twórców staje się gotowość i umiejętność zaadoptowania się do zasad wyznaczanych przez logikę poszerzonego pola kultury, w którym artyści dysponują tradycyjną skrzynką zasobów, ale muszą je wykorzystać w nowych warunkach gry. Przed artystami otwierają się więc nieznane dotąd wyzwania. Kultura, w tym także dzieła twórców, ma pełnić nowe role i odpowiadać na szerszy niż dawniej zestaw celów. Artystów zaprasza się do zaangażowania w nietradycyjne konteksty działalności i oczekuje, że będą uczestniczyć w procesie przybliżania kultury i sztuki różnym grupom odbiorców.

Jednocześnie artyści z dystansem przyglądają się zmianom w polu kultury, do nowych uwarunkowań prowadzenia aktywności twórczej podchodząc z ostrożnością, by nie powiedzieć: nieufnością czy niechęcią. Najczęściej nie wynika to jednak z braku woli czy motywacji do wprowadzania zmian do dotychczasowych trajektorii karier, ale z obawy przed utratą autonomii, jaka wiąże się ze statusem artysty, oraz deficytem zasobów, jakie niezbędne są do podejmowania nowych ról i rekonfigurowania dynamiki własnych karier. Artystom zależy przede wszystkim na redukowaniu bardzo silnego doświadczenia niepewności i niestabilności, jakie towarzyszą byciu twórcą. Obok pojedynczych przykładów osób chętnie i umiejętnie adaptujących się do menedżerialnych uwarunkowań uprawiania działalności artystycznej w świecie społecznym artystów powszechne są wątpliwości związane z internalizacją wzoru przed- 
siębiorcy samego siebie. Przywiązanie do twórczej autonomii albo sprawia, że artyści wychodzą poza własne strefy komfortu niechętnie, albo szukają alternatywnych strategii radzenia sobie z wyzwaniami, jakie generuje poszerzone pole kultury. Symbolicznym przykładem takiego hakowania reguł gry jest fakt, że stojąc w obliczu wystąpienia z wnioskiem o otrzymanie grantu na realizację wydarzenia, twórcy mogą preferować ich samodzielne sfinansowanie.

Hybrydowe tożsamości artystyczne są możliwe do zaakceptowania - choć bywa i tak, że są generalnie przez artystów cenione i uważane za źródło twórczego rozwoju - jeśli nie stoją w sprzeczności z systemem wartości, jaki dany twórca wyznaje. Z uwagi na fakt, że polityki kulturalne poszerzonego pola kultury w ograniczonym stopniu sprzyjają twórcom - artyści doświadczają deficytu wsparcia w instytucjach kultury, brakuje rozwiązań szytych na miarę ich potrzeb i możliwości, a pula dostępnych zasobów na realizację działań kulturalnych jest skromna (Zawistowski 2017) - artyści stosują pragmatyczne strategie adaptacji do nowych reguł gry. Co więcej, generalny kształt i formuła tych strategii jest podobna w całym przekroju świata społecznego artystów. Pewne przesunięcie zauważalne jest ze względu na wiek - młodsi twórcy w większym stopniu są skłonni do internalizacji modelu artysty jako przedsiębiorcy samego siebie, choć różnice między pokoleniami nie są w tym względzie bardzo wyraźne. Zaskakująco podobne są też narracje o dynamikach karier artystów z rdzenia metropolii i ośrodków peryferyjnych. Mimo różnic w dostępie do zasobów istnieje znacznie więcej punktów stycznych niż różnic między artystami z centrum i z „interioru” w kontekście zarządzania trajektoriami własnych biografii zawodowych. Analogicznie, co być może najbardziej zaskakujące, trudno wyodrębnić jednoznacznie „męskie” lub „kobiece" strategie zmagań z osiąganiem sukcesu (zob. np. Wagner, Wodak 2006; Młodożeniec, Knapińska 2013). Być może wynika to z faktu, że zarówno kobiety, jak i mężczyźni (a nie tylko kobiety) doświadczają w roli artystów znacznych trudności i niewygód, co sprawia, że narracje zarówno twórców, jak i twórczyń nie różnią się w sposób zasadniczy.

Warto też podkreślić, że ewentualna większa gotowość do funkcjonalnego adaptowania się do nowych reguł gry w polu kultury nie znajduje bezpośredniego przełożenia na sposób rozumienia sukcesu. Nawet wówczas, gdy artyści wcielają się w role sprawczych przedsiębiorców i menedżerów własnych karier, nie zawsze upatrują $\mathrm{w}$ tych dokonaniach własnego sukcesu. Ten bowiem pozostaje czymś ulotnym, niepewnym i niejednoznacznym, rzadkim i zależnym w znacznej mierze od przypadku (Menger 2018), generującym koszty, napięcia i potencjalne konflikty ról (Dyoniziak 1968; Kos 2018). Wymagające reguły gry w poszerzonym polu kultury, z silną konkurencją, nieczytelnymi uwarunkowaniami i wysokimi wymaganiami na czele, jeszcze wyraźniej każą artystom kwestionować znaczenia, jakie przypisuje się kategorii sukcesu. Sprawiają, że twórcy wyraźniej uwewnętrzniają doświadczenie sukcesu i w dążeniu do jego osiągnięcia stosują strategię, którą nazywam w tekście defensywno-kompensacyjną. Być może więc, odwołując się w zakończeniu do tytułowej metafory biegu z przeszkodami, mimo że bieg jest coraz dłuższy, przeszkody coraz trudniejsze do pokonania, a konkurencja o zajęcie czołowych miejsc konsekwentnie wzmaga się, artyści próbują biec powoli, po swojemu lub nie przystępować do startu w biegu w ogóle. Kwestionują tym samym narzucone z góry zasady gry i wybierają inną drogę - taką, która być może nie pozwala na zdobycie głównej nagrody (wielkich pieniędzy, masowej popularności i pamięci pokoleń), ale dostarcza wiele satysfakcji i niezapomnianych przeżyć. 


\section{Bibliografia}

Abbing Hans (2002) Why Are Artists Poor? The Exceptional Economy of the Arts. Amsterdam: Amsterdam University Press.

Allen Paul (2014) Artist Management for the Music Business. New York: Routledge.

Bachórz Agata, Stachura Krzysztof (2015a) Trajektorie sukcesu artystycznego. Strategie adaptacji artystów w polu kultury. Gdańsk: Instytut Kultury Miejskiej.

Bachórz Agata, Stachura Krzysztof (2015b) W poszukiwaniu punktów stycznych. Rekonstrukcja dyskursu o problemach (nie)uczestnictwa w kulturze. Gdańsk: Instytut Kultury Miejskiej.

Bachórz Agata i in. (2016) Kulturalna hierarchia. Nowe dystynkcje i powinności w kulturze a stratyfikacja społeczna. Gdańsk: Instytut Kultury Miejskiej.

Bachórz Agata i in. (2019) Gra w kulturę. Przemiany pola kultury w erze poszerzenia. Gdańsk: Instytut Kultury Miejskiej.

Baczko-Dombi Anna, Wysmułek Ilona (2014) Czynniki sukcesu. Ciężka praca i talent czy pochodzenie i szczęście? IFiS PAN: Zespół Porównawczych Analiz Nierówności Społecznych [dostęp 3 lutego 2020 r.]. Dostępny w Internecie: http://polishpanelsurvey. files.wordpress.com/2014/03/polpan_czynniki-sukcesu.pdf».

Battenfield Jackie (2009) The Artist's Guide. How to Make a Living Doing What You Love. Boston: Da Capo Lifelong Books.

Becker Howard S. (2008) Art Worlds. 25th Anniversary Edition. Updated and Expanded. Berkeley, Los Angeles, London: University of California Press.

Beeching Angela Myles (2010) Beyond Talent: Creating a Successful Career in Music. Oxford: Oxford University Press.

Belfiore Eleonora (2002) Art as a Means of Alleviating Social Exclusion: Does It Really Work? A Critique of Instrumental Cultural Policies and Social Impact Studies in the UK. "International Journal of Cultural Policy", vol. 8, no. 1, s. 91-106.

Bendassolli Pedro F., Wood Jr. Thomaz (2012) Careers Boundaries in the Arts in Brazil: An Exploratory Study. "The Qualitative Report", vol. 17, s. 1-27 [dostęp 15 sierpnia 2019 r.]. Dostępny w Internecie: ‘http://www.nova.edu/ssss/QR/QR17/bendassoli.pdf`.
Blumer Herbert (2008) Interakcjonizm symboliczny. Perspektywa i metoda. Przełożyła Grażyna Woroniecka. Kraków: Zakład Wydawniczy Nomos.

Błaszczyk Mateusz, Cebula Michał (2016) Uczestnictwo w kulturze a uczestnictwo w mieście. O kapitałach kulturowych i różnorodności stylów życia mieszkańców dużego miasta. „Studia Socjologiczne", t. 1, s. 100-126.

Bogacz-Wojtanowska Ewa i in. (2015) Ogólnopolskie Badanie Losów Zawodowych Absolwentów Uczelni Artystycznych - raport ogólny. Kraków [dostęp 15 sierpnia 2019 r.]. Dostępny w Internecie: 〈http://artystapostudiach.pl/public/download/ Badanie\%20Los\%C3\%B3w\%20Zawodowych\%20Absolwent\%C3\%B3w\%20Uczelni\%20Artystycznych.\%20Raport\%20z\%20 bada\%C5\%84\%20ilo\%C5\%9Bciowych\%202017.pdf .

Boltanski Luc, Chiapello Eve (2007) The New Spirit of Capitalism. London: Verso.

Bourdieu Pierre (1993) The Field of Cultural Production. Essays on Art and Literature. Cambridge: Polity Press.

Bourdieu Pierre (1996) The Rules of Art. Genesis and Structure of the Literary Field. Cambridge: Polity Press.

Bowness Alan (1989) The Conditions of Success. How the Modern Artist Rises to Fame. London: Thames \& Hudson.

Bridgstock Ruth S. (2013) Professional Capabilities for Twenty-First Century Creative Careers: Lessons from Outstandingly Successful Australian Artists and Designers. „The International Journal of Art and Design Education", vol. 32, no. 2, s. 176-189.

Burland Karen, Davidson Jane W. (2002) Training the Talented. „Music Education Research”, vol. 4, no. 1, s. 121-140.

Charmaz Kathy (2009) Teoria ugruntowana. Praktyczny przewodnik po analizie jakościowej. Przełożyła Barbara Komorowska. Warszawa: Wydawnictwo Naukowe PWN.

Czarnecki Sławomir i in. (2012) Poszerzenie pola kultury. Diagnoza potencjału sektora kultury w Gdańsku. Gdańsk: Instytut Kultury Miejskiej.

Denzin Norman K. (1990) Reinterpretacja metody biograficznej $w$ socjologii: znaczenie a metoda $w$ analizie biograficznej [w:] Jan 
Włodarek, Marek Ziółkowski, red., Metoda biograficzna w socjologii. Warszawa, Poznań: Wydawnictwo Naukowe PWN, s. 55-69.

Dobosz Katarzyna, Jarmuł Agnieszka, Poręba Adam, red. (2011) Kultura szeroka. Ksiegga wyjścia na przykładzie 25 lubelskich środowisk kulturalnych. Lublin: Ośrodek „Brama Grodzka - Teatr NN”.

Domański Henryk (2012) Prestiż. Toruń: Wydawnictwo Naukowe Uniwersytetu Mikołaja Kopernika.

Drozdowski Rafał (2017). Dlaczego trudno brać kulturę na serio?. „Kultura i Rozwój”, t. 3, nr 4, s. 41-52.

Dyoniziak Ryszard (1968) Awans społeczny a poczucie sukcesu lub zawodu życiowego. „Ruch Prawniczy, Ekonomiczny i Socjologiczny", t. 30, nr 1, s. 253-270.

Fatyga Barbara (2017) Teoria żywej kultury: źródła i powody jej powstania. „Kultura i Rozwój”, t. 3, nr 4, s. 29-39.

Fatyga Barbara, Dudkiewicz Magdalena, Tomanek Paweł (2012) „Kultura pod pochmurnym niebem”. Dynamiczna diagnoza kultury Warmii i Mazur. Raport i rekomendacje praktyczne. Olsztyn, Warszawa: Centrum Inicjatyw i Edukacji Kulturalnej.

Folga-Januszewska Dorota, Kiliszek Joanna, red., (2018) Wizualne Niewidzialne. Sztuki wizualne w Polsce. Stan, rola $i$ znaczenie. Warszawa: Akademia Sztuk Pięknych w Warszawie.

Forkert Kirsten (2013) Artistic Lives. Surrey, Burlington: Ashgate.

Foucault Michel (2011) Narodziny biopolityki. Przełożył Michał Herer. Warszawa: Wydawnictwo Naukowe PWN.

Giddens Anthony (1991) Modernity and Self-Identity: Self and Society in the Late Modern Age. Cambridge: Polity Press.

Giuffre Katherine (1999) Sandpiles of Opportunity: Success in the Art World. „Social Forces”, vol. 77, no. 3, s. 815-832.

Gladwell Malcolm (2008) Outliers. The Story of Success. New York, Boston, London: Little, Brown and Company.

Gładys-Jakóbik Jolanta, Książkiewicz Izabela (2005) Podsumowanie: polska miara sukcesu [w:] Jolanta Gładys-Jakóbik, red., Różne oblicza i uwarunkowania sukcesu we wspótczesnej Polsce. Warszawa: Szkoła Główna Handlowa, s. 133-146.

Grant Daniel (2010) The Business of Being an Artist. Fourth Edition. New York: Allworth Press.
Grzeszczyk Ewa (2003) Sukces: amerykańskie wzory - polskie realia. Warszawa: Wydawnictwo IFiS PAN.

Hauser Arnold (1974) Społeczna historia sztuki i literatury, t. 2. Warszawa: Państwowy Instytut Wydawniczy.

Heinich Nathalie (2007) Być artysta. Rzecz o przekształceniach statusu malarzy i rzeźbiarzy. Warszawa: Vizja Press \& IT.

Hughes Diane i in. (2013) What constitutes artist success in the Australian music industries?. „International Journal of Music Business Research", vol. 2, no. 2, s. 61-80.

Ilczuk Dorota (2017) Wsparcie dla twórców i artystów. Perspektywa międzynarodowa. Warszawa: Uniwersytet SWPS, Wydział Nauk Humanistycznych i Społecznych.

Ilczuk Dorota i in. (2015) Artyści na rynku pracy. Kraków: Attyka.

Kaczmarek Stella, Posłuszna Joanna (2019) Uwarunkowania finansowania twórców i artystów w Polsce. „Optimum. Economic Studies", t. 3, nr 97, s. 177-188.

Kłosowski Wojciech, red., (2011) Kierunek kultura. W stronę żywego uczestnictwa w kulturze. Warszawa: Mazowieckie Centrum Kultury i Sztuki.

Kos Ewa Arleta (2018) Doświadczenia biograficzne kobiet odnoszacych sukcesy zawodowe. Warunki uczestnictwa społecznego. Łódź: Wydawnictwo Uniwersytetu Łódzkiego.

Kowalewski Maciej, Nowak Anna, Thurow Regina (2015) Nowe role środowisk twórczych: pracownicy socjalni, terapeuci, doradcy [dostęp 15 sierpnia 2019 r.]. Dostępny w Internecie: 〈https://www.academia. edu/19969733/M._Kowalewski_A._Nowak_R._Thurow_2015_ Nowe_role_\%C5\%9Brodowisk_tw\%C3\%B3rczych_pracownicy_ socjalni_terapeuci_doradcy._Raport_z_bada\%C5\%84».

Kozłowski Michał, Sowa Jan, Szreder Kuba (2014a) Fabryka sztuki. Podział pracy oraz dystrybucja kapitałów społecznych w polu sztuk wizualnych we wspótczesnej Polsce. Warszawa: Wolny Uniwersytet Warszawy.

Kozłowski Michał, Sowa Jan, Szreder Kuba (2014b) Konkluzje badania: prekarność, projekt i miłość do sztuki [w:] ciż, Fabryka sztuki. Podziat pracy oraz dystrybucja kapitałów społecznych w polu sztuk wizualnych we wspótczesnej Polsce. Warszawa: Wolny Uniwersytet Warszawy, s. 34-76.

Krajewski Marek (2013) W kierunku relacyjnej koncepcji uczestnictwa w kulturze. „Kultura i Społeczeństwo”, t. 1, s. 29-67. 
Krajewski Marek (2017) „Ja poszerzam”, „Ty poszerzasz”... Poszerzanie pola kultury i wynikajace stad nieporozumienia [w:] Cezary Obracht-Prondzyński, Piotr Zbieranek, red., Pomorskie poszerzenie pola kultury. Dylematy - konteksty - dziatania. Gdańsk: Nadbałtyckie Centrum Kultury, Pomorskie Centrum Badań nad Kulturą UG, s. 29-42.

Krajewski Marek, Schmidt Filip (2017) Co to znaczy być artystal artystka. „Kultura i Społeczeństwo”, t. 1, s. 69-97.

Krajewski Marek, Schmidt Filip (2018) Wyniki badań [w:] Dorota Folga-Januszewska, Joanna Kiliszek, red., Wizualne Niewidzialne. Sztuki wizualne w Polsce. Stan, rola i znaczenie. Warszawa: Akademia Sztuk Pięknych w Warszawie, s. 3-124.

Kurz Iwona (2019) Powrót centrali, państwowcy wyklęci i kasa. Raport $z$ "dobrej zmiany” w kulturze. Warszawa: Instytut Studiów Zaawansowanych.

Lahire Bernard (2010) The Double Life of Writers. „New Literary History", vol. 41, no. 2, s. 443-465.

Leśniewski Andrzej (2015) Wizerunek artysty kreowany rzadowymi/samorzadowymi politykami kulturalnymi [w:] Natalia Brylowska, Anna Pekaniec, red., Sztuka, polityka, pieniadze. Sytuacja artysty w świecie wspótczesnym. Gdańsk: Instytut Kultury Miejskiej, s. 51-62.

Lewicki Mikołaj, Filiciak Mirosław (2017) Wynalezienie poszerzonego pola kultury. „Kultura i Rozwój”, t. 1, nr 2, s. 7-31.

Lysgård Hans Kjetil (2013) The Definition of Culture in Culture-Based Urban Development Strategies: Antagonisms in the Construction of a Culture-Based Development Discourse. "International Journal of Cultural Policy", vol. 19, no. 2, s. 182-200.

Łazarowicz-Kowalik Marta (2015) Anatomia sukcesu w nauce. Studium socjologiczne laureatów konkursów fundacji na rzecz nauki polskiej [dostęp 3 lutego 2020 r.]. Dostępny w Internecie: ‘https:// depotuw.ceon.pl/bitstream/handle/item/1448/praca\%20doktorska_Marta\%20\%C5\%81azarowicz-Kowalik.pdf .

Łuczaj, Kamil (2018) Sytuacja estetyczna w świecie agencji reklamowych. Co socjologia reklamy może zaczerpnać z estetyki $i$ socjologii sztuki?. „Pogranicze. Studia Społeczne”, t. 34, s. 64-84.

Menger Pierre-Michel (2018) Inequalities in the Arts [w:] Jeffrey A. Halley, Daglind E. Sonolet, eds., Bourdieu in Question. New Directions in French Sociology of Art. Leiden, Boston: Brill, s. 161-180.
Merton Robert K. (1968) The Matthew Effect in Science. „Science", vol. 159, s. 56-63.

Młodożeniec Marek, Knapińska Anna (2013) Czy nauka wcią̇ ma męska pteć? Udział kobiet w nauce. „Nauka”, t. 2, s. 47-72.

Możdżyński Paweł (2018) Eventy i projekty. Transfery innowacji pomiędzy polem sztuki a życiem codziennym i gospodarkq w XX i XXI wieku. „Pogranicze. Studia Społeczne”, t. 34, s. 7-18.

Mulkay Michael, Chaplin Elizabeth (1982) Aesthetics and the Artistic Career: A Study of Anomie in Fine-Art Painting. "The Sociological Quarterly", vol. 23, s. 117-138.

Murzyn-Kupisz Monika, Działek Jarosław, red., (2017) The Impact of Artists on Contemporary Urban Development in Europe. Cham: Springer.

Osęka Andrzej (1975) Mitologie artysty. Warszawa: Państwowy Instytut Wydawniczy.

Pinheiro Diogo L., Dowd Timothy J. (2009) All That Jazz: The Success of Jazz Musicians in Three Metropolitan Areas. "Poetics", vol. 37, s. 490-506.

Platman Kerry (2004) 'Portfolio Careers' and the Search for Flexibility in Later Life. "Work, Employment and Society”, vol. 18 , no. 3, s. 573-599.

Prus Robert (1995) Symbolic Interaction and Ethnographic Research. Intersubjectivity and the Study of Human Lived Experience. Albany: State University of New York Press.

Rokicka Ewa, Kruczkowska Patrycja (2013) Instytucje kultury i ich wykluczeni [w:] też, red., Ekskluzja w dyskursie pracowników instytucji kultury. Łódź: Katedra Socjologii Ogólnej Uniwersytetu Łódzkiego, s. 2-24.

Sadura Przemysław (2017) Poszerzanie bez uprzedzeń. Instytucje lokalne i podziały społeczne w nowym dyskursie o kulturze. „Kultura i Rozwój”, t. 3, nr 4, s. 53-70.

Shibutani Tamotsu (1955) Reference Groups as Perspectives. "American Journal of Sociology", vol. 60, s. 562-569.

Siechowicz Paweł, Wiśniewska Aleksandra, Kurek Przemysław (2016) Inwestycje w kulturze a bieżaca działalność kulturalna w latach 2001-2013. Warszawa: Narodowe Centrum Kultury. 
Strauss Anselm (1978) A Social World Perspective [w:] Norman Denzin, ed., Studies in Symbolic Interaction, Volume 1. Greenwich: JAI Press, s. 119-128.

Szreder Kuba (2018) Instituting the Common in Artistic Circulation: From Entrepreneurship of the Self to Entrepreneurship of the Multitude. „Praktyka Teoretyczna”, t. 1, nr 27, s. 193-223.

Szulborska-Łukaszewicz Joanna (2017) Zarzadzanie $i$ teatr. O statusie artysty w Polsce. "Zarządzanie w Kulturze”, t. 18, nr 3, s. 373-394.

Wagner Ina, Wodak Ruth (2006) Performing success: identifying strategies of self-presentation in women's biographical narratives. „Discourse \& Society”, vol. 17, no. 3, s. 385-411.

Wagner Izabela (2015) Producing Excellence. The Making of Virtuosos. New Brunswick: Rutgers University Press.

Walczak Wojciech, Wyrzykowska Katarzyna M., Socha Ziemowit (2016) Dynamika karier muzyków w obszarze całego środowiska muzycznego. Warszawa: Fundacja Polskiej Rady Muzycznej.
Woźniak Wojciech (2013) Instytucja kultury jako miejsce pracy. Wnioski z wywiadów swobodnych [w:] Ewa Rokicka, Patrycja Kruczkowska, red., Ekskluzja w dyskursie pracowników instytucji kultury. Łódź: Katedra Socjologii Ogólnej Uniwersytetu Łódzkiego, s. 146-178.

Wyrzykowska Katarzyna M., Zawadzka Kinga (2018) Wybrańcy czy ofiary losu? Kilka uwag o prestiżu zawodowym osób wykonujacych profesje muzyczne w Polsce. „Pogranicze. Studia Społeczne", t. 34, s. 149-169.

Zawistowski Władysław (2017) Poszerzajac, nie zapominajmy o punkcie odniesienia [w:] Cezary Obracht-Prondzyński, Piotr Zbieranek, red., Pomorskie poszerzenie pola kultury. Dylematy konteksty - działania. Gdańsk: Nadbałtyckie Centrum Kultury, Pomorskie Centrum Badań nad Kulturą UG, s. 297-300.

Znaniecki Florian (1937) Rola społeczna artysty. „Wiedza i Życie", t. 8/9, s. 13-31.

Zolberg Vera L (2015) A Cultural Sociology of the Arts. „Current Sociology Review", vol. 63, no. 6, s. 896-915.

\title{
Cytowanie
}

Stachura Krzysztof (2020) Bieg z przeszkodami. Ambiwalencje sukcesu artystycznego w poszerzonym polu kultury. „Przegląd Socjologii Jakościowej", t. 16, nr 2, s. 102-127 [dostęp dzień, miesiąc, rok]. Dostępny w Internecie: ‘www.przegladsocjologiijakosciowej. org>. DOI: http://dx.doi.org/10.18778/1733-8069.16.2.07

\section{The Steeplechase: The Ambivalence of Artistic Success Within a Broadened Field of Culture}

\begin{abstract}
The purpose of the paper is to analyze the ambivalent character of success in the social world of artists. The analysis is conducted taking into account the context of the broadened field of culture, and special attention is paid to the set of meanings that artists attach to success. Much of the discussion revolves around the significance of the transformation of the field of culture for artists' adaptation strategies. In consequence, the paper deals with the reconstruction of managing artist careers while taking into consideration their precarious experiences in the field of arts. Empirical material is used to depict the difficulties and doubts regarding reaching success in art worlds as well as to explain the determinants of the defensive and compensative strategy of managing success. As a result, conclusions are drawn concerning the means artists use to hack the rules of the game in the broadened field of culture.
\end{abstract}

Keywords: artistic success, adaptation strategies, career dynamics, the broadening of the field of culture, cultural sector 